\title{
Not all clawbacks are the same: Consequences of strong versus weak clawback provisions ${ }^{i 2}$
}

\author{
Michael H.R. Erkens ${ }^{\mathrm{a}, *}$, Ying Gan ${ }^{\mathrm{a}}$, B. Burcin Yurtoglu ${ }^{\mathrm{b}}$ \\ a ERASMUS School of Economics, ERASMUS University Rotterdam, 3062 PA Rotterdam, The Netherlands \\ ${ }^{\mathrm{b}}$ WHU Otto-Beisheim-School of Management, 56179 Vallendar, Germany
}

\section{A R T I C L E I N F O}

\section{Keywords:}

Clawback provisions

Corporate governance

Linguistic analysis

Reporting quality

JEL codes:

G30

G34

G35

K22

M21

M41

\begin{abstract}
A B S T R A C T
We develop a Clawback Strength Index and show that while some firms adopt unambiguous and strong clawback provisions, others adopt weak ones. We find that strong clawback adopters experience improvements in financial reporting quality, fewer CEO turnovers, and lower CEO pay. We advance two possible explanations: First, clawback strength may be primarily responsible for the improvements in reporting quality. Second, strong clawbacks may yield benefits because they are part of a broader reform package. While our findings on reporting quality and CEO turnover are consistent with both explanations, our results on CEO pay support only the broader reform explanation.
\end{abstract}

\section{Introduction}

Clawback provisions ("clawbacks") authorize firms to recoup compensation from executives upon the occurrence of financial restatements or executive misbehavior. Clawbacks were first introduced by Section 304 of the Sarbanes-Oxley Act of 2002 (hereafter, SOX 304). SOX 304 requires CEOs and CFOs to return any earned incentive compensation following a financial restatement due to misconduct and puts the burden of enforcement on the Securities and Exchange Commission (SEC). Next to SOX 304, Section 954 of the Dodd-Frank Wall Street Reform and Consumer Protection Act (hereafter, DFA) introduced clawback rules in 2010 requiring firms to adopt and enforce clawback provisions themselves. While Section 954 is not yet carved into law, many firms have voluntarily started to adopt clawbacks. As of 2013, about 45\% of Russell 3000 non-financial firms had such voluntary provisions in place.

Most studies report strong evidence that firm-initiated clawbacks are effective in improving financial reporting quality (Chan et al., 2012; deHaan et al., 2013), and that investors respond positively to clawback adoption (e.g., Iskandar-Datta and Jia, 2013).

\footnotetext{
We owe special thanks to Jeroen Suijs for his insights, valuable comments, and suggestions. We are also grateful to comments and suggestions from John Core (editor) and an anonymous referee. We gratefully acknowledge comments by Axel Adam-Mueller, Walid Alissa, Raul Barroso, Bernard Black, Feng Chen, Hans B. Christensen, Ed de Haan, Thomas Keusch, Edith Leung, Christian Leuz, Garen Markarian, Gaizka Ormazabal, Buhui Qiu, Sander Renes, Eddie Riedl, Nemit Shroff, Hervé Stolowy, David Veenman, David Yermack, Teri L. Yohn, and seminar participants at Erasmus University, HEC Paris, UNSW, Universidad Carlos III, University of Sydney, and WHU Otto-Beisheim-School of Management. We also thank participants of the Academy of Management Annual Meeting (2014), the American Accounting Association Annual Meeting (2014), the European Accounting Association Annual Meeting (2014, 2015), the Berlin Accounting Conference (2018), the European Financial Management Annual Meeting (2015), the Global Finance Conference (2014), and the International Conference of the Journal of International Accounting Research (2014). We also thank Marije Minkman and Natalie Reid for their linguistic consulting. Part of this work was done while Michael H.R. Erkens was visiting the University of Chicago and Ying Gan was visiting HEC Paris.

* Corresponding author.

E-mail addresses: erkens@ese.eur.nl (M.H.R. Erkens), gan@ese.eur.nl (Y. Gan), burcin.yurtoglu@whu.edu (B.B. Yurtoglu).
} 
These studies treat clawbacks as a binary choice: A firm either does or does not have a clawback. The common interpretation of these results is that the mere adoption of the clawback is the primary cause of the observed benefits.

The strength and uniformity of the effects attributed to clawback adoption is striking for two reasons: First, firms have considerable freedom to design clawbacks. This freedom likely leads to a huge variation in clawback design across firms, which can either draft weak provisions that indicate clawback adoption merely in name or draft strong provisions. Because executives are likely to respond differently to these two types of clawbacks (Fried and Shilon, 2011), one can expect differential economic outcomes conditional on clawback design, rather than a uniform effect due to adoption. Thus, given that clawback design affects executives' behavior differently, the results found in prior studies should be interpreted with caution: The improvements in reporting quality may not be the causal effect of adopting a clawback per se but rather the effect of adopting a clawback with a specific design.

Second, prior studies focus mainly on reporting risk driven by the CEO's reporting decision. They do not account for reporting risk driven by factors beyond the CEO's immediate control. However, if firms truly care about their reporting quality, they are likely to take measures to reduce overall reporting risk. Then again, the improvements in reporting quality may be interpreted not as the sole effect of adopting a clawback in isolation but as an outcome driven by the combined effect of adopting a clawback with a specific design and other simultaneous actions the firm takes to improve its reporting.

This study addresses these two concerns by both analyzing clawback design and distinguishing between two types of reporting risk. As opposed to earlier studies on clawbacks, all of which focus on whether a firm adopts a clawback or not, we analyze the crosssectional variation in clawback design. We capture differences in clawback design by performing a comprehensive linguistic analysis of 4,464 voluntarily adopted clawbacks between 2007 and 2013. Drawing on the linguistic analysis, we create an index for capturing the strength of clawbacks (Clawback Strength Index). This index is based on five components that determine clawback strength: (1) the compensation types that are subject to a potential recoupment, (2) the employee groups that are covered by the clawback, (3) the extent to which the clawback mandates its enforcement, (4) the time period to which the clawback pertains, and (5) the various events that trigger a potential compensation recoupment.

We find a substantial variation in both the focus and scope of clawback design. We distinguish between two types of clawback provisions: (a) provisions whose design suggests that clawback adoption is in name only and (b) provisions whose design indicates a firm's intention to put real pressure on executives. We call type (a) "weak clawbacks" and type (b) "strong clawbacks." Given that firms understand the nature of clawbacks (Fried and Shilon, 2011), we can reasonably assume that they consciously choose a specific design.

We argue that overall reporting risk consists of two components: controllable and non-controllable reporting risk. Controllable reporting risk is the risk of a restatement caused by the CEO's decision to misreport. Non-controllable reporting risk is the risk of a restatement caused by factors beyond the CEO's immediate control. This risk is affected by properties of the contracting environment of the firm that is shaped by other actors, such as the reporting decisions of lower level managers or monitoring intensity of external auditors or boards. We assume that by initiating a clawback provision, the firm may change the CEO's reporting decision, thereby reducing the controllable reporting risk but not the non-controllable reporting risk. ${ }^{1}$ Moreover, we assume that controllable reporting risk decreases when clawbacks are strong. Yet firms that seriously care about their reporting may not solely rely on the strong clawback. They are also likely to take other simultaneous actions to reduce non-controllable reporting risk.

We therefore advance two explanations for both our findings and those of earlier studies: one that draws causal effects based on clawback design (the isolated clawback explanation), not clawback adoption per se, and another one that also encompasses clawback adoption as part of a firm's broader reform to reduce reporting risk overall (the broader reform explanation).

Because the CEO's expected costs from misreporting increase in clawback strength, we predict improvements in reporting quality for strong clawback adopters. Furthermore, we also expect to observe improvements in reporting quality if the firm simultaneously decreases non-controllable reporting risk as well.

Given that restating firms more often experience executive turnovers following a restatement (Desai et al., 2006), we expect to observe fewer CEO turnovers if there are fewer incidences of financial restatements due to the reduction of controllable or noncontrollable reporting risk or both. Thus we predict a decrease in the likelihood of a CEO turnover for strong adopters.

The distinction between controllable and non-controllable risk also has implications for CEO pay. If firms adopt a clawback solely in isolation but do not simultaneously reduce non-controllable reporting risk, we predict an increase in CEO incentive pay: Strong clawbacks penalize the CEO for both controllable and non-controllable reporting risk. Because the CEO's expected costs stemming from the exposure to non-controllable reporting risk increase after the adoption of a strong clawback, the board needs to increase CEO incentive pay to induce him or her to exert effort. Thus observing an increase in pay is consistent with the isolated clawback explanation. However, if firms adopt the strong clawback as part of a broader reform, together with other simultaneous actions to reduce reporting risk, the overall package likely also reduces the CEO's expected costs associated with non-controllable reporting risk. As non-controllable risk decreases, the need for increasing incentive pay also decreases. Indeed, when non-controllable reporting risk is reduced to sufficiently low levels, even a decrease in incentive pay may be feasible. Therefore, observing a decrease in pay would refute the isolated clawback explanation while remaining consistent with the broader reform explanation.

Using a difference-in-differences (DiD) design combined with a propensity-score method that matches strong adopters to weak adopters, we test our predictions by analyzing the consequences following the adoption of strong or weak clawbacks. Our findings are

\footnotetext{
${ }^{1}$ Our distinction between controllable and non-controllable risk resembles the notion of "discretionary" vs. "innate" determinants of accruals quality in Francis et al. (2005): Discretionary factors represent managerial choices and are similar to controllable risk, whereas innate ones resemble our notion of noncontrollable risk.
} 
consistent with our predictions that adopters of strong provisions experience (1) improvements in reporting quality, as evidenced by a lower incidence of financial restatements and other measures of reporting quality, (2) decreases in the likelihood of a CEO turnover, and (3) a decrease in total and incentive-based CEO pay.

In subsequent analyses, we also separately compare matched pairs of strong (weak) clawback adopters and non-clawback adopters. We find that while strong clawback adopters experience significant beneficial changes in firm-level outcomes, weak clawback adopters do not. Therefore, weak clawbacks appear ineffective.

Taken together, the changes in reporting quality and CEO turnover can be reconciled with both the isolated clawback and the broader reform explanations. Strong clawbacks, either as a stand-alone mechanism or as part of a broader reform, are responsible for the documented benefits. However, the decrease in CEO pay supports only the broader reform explanation. This explanation implies that our findings reflect the overall causal effect of a broader reform, not the purely causal effect of clawback strength.

Our study contributes to the literature on clawbacks in several ways. First, we provide novel evidence on clawback design. We quantify the strength of clawbacks and show that firms with strong clawbacks experience beneficial firm-level outcomes, while firms with weak clawbacks do not. In contrast to earlier clawback studies, we emphasize the importance of specific clawback design choices. Second, studying the design of corporate governance mechanisms is useful for making inferences about firms' motives for adopting such mechanisms. We therefore suggest that future research pay more attention to the design of governance tools. Third, our study offers and discusses two non-mutually exclusive explanations for our findings: The isolated clawback and the broader reform explanations. The broader reform explanation provides a more comprehensive interpretation of our full set of results, without rejecting the possibility that strong clawbacks may act as a powerful tool as part of the broader reform package. From this perspective, one can view the isolated clawback explanation as being embedded within the broader reform explanation. Fourth, clawback strength can be interpreted as a proxy for the elements of a broader reform, elements that are implemented simultaneously with the clawback. Because these elements likely vary across time and firms, capturing them in the cross-section is difficult. In contrast, clawback strength is observable. The documented decrease in CEO pay and our findings that the economic benefits of clawbacks are concentrated only among strong adopters suggest that clawback strength can proxy for the unobservable elements of a broader reform.

The rest of the paper is organized as follows. Section 2 presents the background on clawbacks, and develops our hypotheses. Section 3 discusses the index construction, our sample, and the research design. Section 4 presents and discusses our findings. Section 5 explores the robustness tests. Section 6 concludes.

\section{Background and hypotheses}

\subsection{Background}

The core objectives of clawback provisions are to prevent accounting misconduct and reduce reporting risk. Whether a voluntary clawback is an effective tool for influencing managerial behavior depends on two factors. The first factor-given that clawback provisions are usually triggered by earnings restatements-is the importance of earnings for executive compensation contracts. Studies report that most firm-related variation in executives' incentives stems from CEOs' stock and option holdings (Hall and Liebman, 1998; Murphy, 1999; Core et al., 2003), thereby raising the question of whether earnings are a relevant contracting variable.

Studies that use recent data report that firms increasingly tie CEO compensation to long-term accounting performance and that earnings can be an important determinant of both cash and stock-based incentive compensation. For example, Li and Wang (2016) study the multiyear accounting-based performance (MAP) contracts of S\&P 500 firms and find that the percentage of firms using them more than doubled between 1997 and 2008. MAP contracts provide economically meaningful incentives: The mean annualized target payout from MAP contracts is two times a CEO's base salary. Li and Wang (2016) show that over 80\% of MAP contracts include at least one earnings-based performance target and that over 50\% rely solely on earnings-based targets. Bennett et al. (2017), using a larger sample from 1998-2012, present similar percentages. Both of these studies suggest that earnings are becoming increasingly important for executive compensation contracts.

The second factor explaining why a voluntary clawback is an effective tool for influencing managerial behavior is the actual threat of recouping incentive pay. As firms voluntarily adopt clawbacks and choose how to design them, this second factor is tightly linked to the specific characteristics of the clawback provisions.

We capture these characteristics by creating a Clawback Strength Index from a linguistic analysis of nearly 4,500 voluntarily adopted clawback provisions (see Section 3.1). The index reveals that clawbacks have different strength levels, indicating that firms use their flexibility in formulating either strong or weak clawbacks. Strong clawbacks have a more comprehensive coverage of clawback features, such as compensation coverage and clawback time period, suggesting higher out-of-pocket costs for executives and, therefore, larger incentivizing effects.

That clawback characteristics correlate with firms' motives to adopt clawback provisions is plausible. If the motive for adoption is window-dressing, we will likely observe the adoption of weak clawbacks. ${ }^{2}$ Another motive for adoption can be the boards' greater commitment to reducing reporting risk (Denis, 2012). In that case, we will likely observe the adoption of strong clawbacks. While

\footnotetext{
${ }^{2}$ The presence of symbolic rather than substantive provisions is consistent with the literature studying the adoption of corporate governance mechanisms. Westphal and Graebner (2010), for example, argue that the adoption of visible governance structures, policies, and procedures can be more symbolic than substantive when they are used primarily for managing the impression of outside observers.
} 
strong clawbacks can incentivize managers to report accurately and monitor financial reporting with due diligence, weak clawbacks are unlikely to provide managers with sufficient incentives.

In sum, financial losses contribute to the costs that executives must face in case of restatements. Such losses may deter executives from engaging in reporting irregularities. However, this potential effect is subject to caveats. First, the link between earnings and managerial incentives may be weaker than earlier clawback studies have assumed. Second, firms can attain even higher deterrence effects with tools such as the renegotiation of compensation contracts and dismissals-tools that were available to them before clawback adoption (Denis, 2012). Supporting this view, various studies document a higher incidence of CEO turnover following accounting irregularities (e.g., Desai et al., 2006; Hennes et al., 2008).

We next develop testable hypotheses. In so doing, we focus on the differences in the strength of clawback provisions and explain the economic mechanisms through which these differences predict differential firm-level consequences.

\subsection{Clawback strength and financial reporting quality}

Our first hypothesis relates to clawback strength and reporting quality. We distinguish between two types of reporting risk that can lead to low reporting quality and a subsequent restatement. The first type of risk is driven by the CEO's reporting decision. We name this type of reporting risk "controllable risk". The second type of risk is beyond the CEO's immediate control. This risk is affected by properties of the contracting environment of the firm and is shaped by other actors, such as the reporting decisions of lower level managers or monitoring intensity of external auditors or boards. We name this type of reporting risk "non-controllable risk." " Non-controllable risk can lead to low reporting quality and a subsequent restatement, even if the CEO reports truthfully.

To fix ideas, we rely on a principal-agent framework with moral hazard (Holmstrom, 1979), in which earnings are an important determinant of CEO incentive pay. In an agency setting, expected compensation is the primary driver of incentives while the compensation risk is the primary driver of the firm's agency cost. To keep our analysis simple, we focus on expected compensation as the determinant of the CEO's decision. ${ }^{4}$ To obtain incentive pay, the CEO can decide to exert costly effort to generate high earnings. Alternatively, the CEO can save costly effort by overstating earnings and untruthfully reporting high earnings. However, misreporting can trigger a restatement and a CEO dismissal, leading to the loss of his or her expected future compensation.

Without a clawback, the CEO will choose to misreport when the benefits of misreporting (not exerting effort and pocketing incentive pay) exceed the expected costs of misreporting (being dismissed and losing expected future compensation). Thus, even when incentive pay is low, the CEO can still choose to misreport when he or she believes that the expected costs of misreporting are relatively low. The introduction of a clawback provision increases the CEO's expected costs of misreporting. In addition to being dismissed and the corresponding loss of future expected compensation with the firm, the CEO now also bears the expected costs of a compensation forfeiture. These costs increase with clawback strength. Consequently, a strong clawback is more likely to incentivize the CEO to not misreport than a weak clawback.

The CEO's decision to report truthfully under a strong clawback is associated with a reduction in expected costs stemming from controllable reporting risk. However, a strong clawback also increases the expected costs stemming from the CEO's exposure to noncontrollable reporting risk: The firm may also recoup CEO incentive pay if non-controllable risk leads to a restatement.

If firms care a great deal about their reporting quality, they are likely to adopt a strong clawback while simultaneously introducing other corporate governance actions for reducing the non-controllable risk. The firm can achieve such reductions in noncontrollable risk, for example, by (a) improving the board's level of oversight, allocating more time and attention to prepare for meetings with executives, engaging in vigorous discussions, and asking probing questions (Laux and Laux, 2009); (b) improving the firm's internal control process (Hermanson et al., 2012); or (c) improving the risk assessment process (Wagner and Dittmar, 2006). Together, these actions constitute a reform package that is broader than merely adopting a clawback. The reform package can lower the CEO's exposure to non-controllable reporting risk and thus allows for a more effective use of a clawback clause.

Thus strong clawbacks-either in isolation as a stand-alone mechanism (the isolated clawback explanation) or in interaction with the other corporate governance actions (the broader reform explanation) ${ }^{5}$-are likely to improve reporting quality, while weak clawbacks are unlikely to do so.

Given these explanations, we formulate the following hypothesis:

H1. Financial reporting quality increases after the adoption of a strong clawback.

\subsection{Clawback strength and CEO turnover}

Our second hypothesis relates to clawback strength and the effect on CEO turnover. Previous studies find a higher incidence of CEO turnover following accounting irregularities (e.g., Desai et al., 2006; Hennes et al., 2008). For example, Desai et al. (2006) report that about $60 \%$ of restating firms experience an executive turnover following a restatement. They argue that the dismissal of the CEO

\footnotetext{
${ }^{3}$ We recognize that the term "non-controllable risk" is imprecise because it may incorporate actions that the CEO can influence-but not as easily or effectively as the controllable risk.

${ }^{4}$ Haubrich (1994), Lien (2002), and Bliss and Penigitzoglou (2004) provide evidence that risk-aversion parameters are generally very low. Thus, as risk aversion appears to have a second-order effect, it will unlikely change either the CEO's reporting decision or our predictions.

5 The broader reform explanation is also in line with previous corporate governance research, which argues that various governance mechanisms interact in potentially important ways (Denis, 2001, 2012).
} 
may act as a partial substitute for public enforcement of accounting violations and may therefore decrease the costs of public enforcement to the firm.

A strong clawback imposes additional costs on CEOs if they misreport. In addition to the costs of a potential turnover, CEOs also face costs related to the clawback. As hypothesized in H1, these additional costs can lead to fewer restatements. We therefore also hypothesize fewer CEO turnovers as a consequence of strong clawbacks. This line of reasoning is consistent with both the isolated clawback and the broader reform explanations. We emphasize that the clawback provision itself does not substitute for a CEO turnover. However, we expect to observe fewer CEO turnovers following the adoption of strong clawbacks, because reporting quality improves.

As with our first hypothesis, we expect changes in the likelihood of a CEO turnover for strong clawback adopters but not for weak ones.

H2. The likelihood of a CEO turnover decreases after the adoption of a strong clawback.

\subsection{Clawback strength and CEO compensation}

Our third hypothesis relates to clawback strength and its effect on CEO compensation. A clawback imposes costs on the CEO stemming from both controllable and non-controllable reporting risks. The firm does not need to compensate the CEO for an increase in expected costs associated with controllable risk as determined by his or her reporting decision. Instead, these costs incentivize the CEO to not misreport (Hypothesis 1). However, if the clawback is adopted in isolation, the increase in expected costs associated with non-controllable reporting risk reduces the CEO's expected pay: He or she may decide not to exert effort because the received incentive pay may be recouped. Therefore, to incentivize the CEO to exert effort under a strong clawback, ceteris paribus, the firm needs to increase CEO incentive pay. ${ }^{6}$

However, the need to increase CEO incentive pay under a strong clawback can be mitigated by a broader reform package that reduces the expected costs associated with non-controllable reporting risk. As non-controllable risk decreases, the need for increasing incentive pay also decreases. Indeed, when non-controllable reporting risk is reduced to sufficiently low levels, even a decrease in incentive pay may be feasible. Therefore, if the firm adopts a strong clawback while simultaneously reducing the expected costs associated with non-controllable reporting risk, we expect either no change or a decrease in incentive pay. A decrease is also consistent with the literature on the relationship between governance and compensation. For example, Dicks (2012) shows that governance and incentive compensation act as substitutes, and Chhaochharia and Grinstein (2009) report a decrease in CEO pay for firms that enhanced their board oversight following the new 2003 governance rules issued by major U.S. stock exchanges.

In sum, the isolated clawback and the broader reform explanations provide opposite predictions for the expected change in CEO pay following the adoption of a strong clawback. Our third hypothesis is therefore stated as competing hypotheses: H3a. (the isolated clawback explanation). CEO incentive pay increases after the adoption of a strong clawback.

H3b. (the broader reform explanation). CEO Incentive pay either remains unchanged or decreases after the adoption of a strong clawback.

\section{Index construction, sample, and methodology}

\subsection{Index construction and sample}

We obtain data on voluntary clawback adoptions from the Corporate Library, which covers all clawbacks of Russell 3000 firms from 2007. We focus on nonfinancial firms that adopt a clawback provision between 2007 and 2013. Panel A of Table 1 shows 4,464 clawback provisions representing a clawback adoption rate of $26.78 \%$ for the entire sample period. Clawbacks became increasingly popular over the years: the adoption rate was $11.63 \%$ in 2007 , increased to $21.42 \%$ in 2009 , and jumped to $45.20 \%$ in 2013 .

To conduct our analyses, we construct a Clawback Strength Index that uses detailed information contained in all provisions to proxy for the strength of a clawback policy. We build the index using a linguistic analysis that relies on the literature on clawback provisions (e.g., Fried and Shilon, 2011; Iskandar-Datta and Jia, 2013) and SEC clawback regulation. Our index is the sum of five subindices, reflecting the core elements of a clawback policy. We check the compensation types covered (Compensation Coverage), the employees subject to potential recoupment (Employee Coverage), the extent to which the clawback mandates enforcement (Enforcement), the time period to which the clawback pertains (Time Period), and the triggering events for a potential recoupment (Trigger).

A clawback is more likely to be classified as strong if it covers a more comprehensive group of employees, if it comprises many components of compensation over a long look-back period, if it obligates the firm to recoup compensation, and if it does not require proof of executive misconduct as a precondition for activating a clawback policy. To ease comparability and interpretation, we first standardize each sub-index so that they all contribute equally to the overall index and then transform each standardized sub-index so that they range within a [0-1] interval. The Clawback Strength Index is then:

\footnotetext{
${ }^{6}$ Adopting a strong clawback can also serve as a costly signal, with the cost being the reduction of CEO incentives, the increase in CEO pay related to noncontrollable reporting risk, or both. Thus mimicking a strong clawback adopter is costly for a firm.
} 
Table 1

Clawback adopters.

Panel A: Number of clawback adopters by year (non-financial Russell 3000 firms)

\begin{tabular}{|c|c|c|c|c|c|c|c|c|}
\hline & 2007 & 2008 & 2009 & 2010 & 2011 & 2012 & 2013 & $2007-2013$ \\
\hline Number of firms with clawbacks & 260 & 397 & 561 & 713 & 784 & 850 & 899 & 4,464 \\
\hline Total number of firms & 2,235 & 2,754 & 2,619 & 2,473 & 2,385 & 2,217 & 1,989 & 16,672 \\
\hline Adoption rate (in \%) & 11.63 & 14.42 & 21.42 & 28.83 & 32.87 & 38.34 & 45.20 & 26.78 \\
\hline
\end{tabular}

Panel B: Clawback Strength Index

\begin{tabular}{|c|c|c|c|c|c|c|}
\hline & Obs. & Mean & SD & Min & Median & $\operatorname{Max}$ \\
\hline Compensation coverage & 4,464 & 0.29 & 0.12 & 0.00 & 0.25 & 1.00 \\
\hline Employee coverage & 4,464 & 0.32 & 0.17 & 0.00 & 0.37 & 1.00 \\
\hline Enforcement & 4,464 & 0.75 & 0.17 & 0.00 & 0.82 & 1.00 \\
\hline Time period & 4,464 & 0.15 & 0.26 & 0.00 & 0.00 & 1.00 \\
\hline Trigger & 4,464 & 0.33 & 0.11 & 0.00 & 0.33 & 1.00 \\
\hline Clawback Strength Index & 4,464 & 1.85 & 0.42 & 0.56 & 1.79 & 3.37 \\
\hline
\end{tabular}

Panel C: Clawback Strength Index (median values) for strong and weak clawback adopters by year

\begin{tabular}{|c|c|c|c|c|c|c|c|c|}
\hline & 2007 & 2008 & 2009 & 2010 & 2011 & 2012 & 2013 & $2007-2013$ \\
\hline Strong and weak adopters & 1.76 & 1.78 & 1.78 & 1.82 & 1.84 & 1.82 & 1.76 & 1.79 \\
\hline Strong adopters & 2.07 & 2.07 & 2.11 & 2.19 & 2.16 & 2.22 & 2.07 & 2.12 \\
\hline Weak adopters & 1.55 & 1.55 & 1.56 & 1.57 & 1.55 & 1.58 & 1.48 & 1.51 \\
\hline
\end{tabular}

Panel D: Sample selection for propensity-score matching

\begin{tabular}{|c|c|c|}
\hline & \# Clawback provisions & Unique firms \\
\hline Full sample of clawback adopters & 4,464 & 1,534 \\
\hline Less: Observations with missing link to Compustat & -440 & -236 \\
\hline Less: Observations with inconsistent clawback strength levels & $-1,002$ & -223 \\
\hline Subsample of clawback adopters & 3,022 & 1,075 \\
\hline Thereof: Strong clawback adopters & 1,520 & 541 \\
\hline Thereof: Weak clawback adopters & 1,502 & 534 \\
\hline Less: Observations with missing data for propensity-score matching in pre-adoption year & -831 & -332 \\
\hline Less: Non-pre-adoption year observations of clawback adopters & $-1,448$ & - \\
\hline Clawback adopters with available data for propensity-score matching in pre-adoption year & 743 & 743 \\
\hline Thereof: Strong clawback adopters & 386 & 386 \\
\hline Thereof: Weak clawback adopters & 357 & 357 \\
\hline Non-clawback adopters with available data for propensity-score matching & 4,585 & 1,278 \\
\hline Firms with available data for propensity-score matching & 5,328 & 2,021 \\
\hline
\end{tabular}

This table Panel A presents the number of firms that voluntarily adopted a clawback provision between 2007 and 2013. Panel B presents summary statistics of the Clawback Strength Index and each of its subindices. Panel C presents the median values of the Clawback Strength Index for strong and weak adopters $(n=4,464)$, strong adopters $(n=2,234)$, and weak adopters $(n=2,230)$ by year. Panel D outlines the sample selection procedure for the propensity-score matching in which we model the decision to adopt a strong clawback, a weak clawback, or no clawback via an ordered-logit model.

\section{Clawback Strength Index $=$ Compensation Coverage + Employee Coverage + Enforcement + Time Period + Trigger}

The index can take a maximum value of 5 and a minimum value of 0 . Higher values indicate stronger provisions. Table 1 , Panel B, shows that the index ranges from 0.56 through 3.37 with a mean (median) of 1.85 (1.79), and a standard deviation of 0.42 . The statistics reveal that the strength of clawbacks differs across firms, indicating that firms value the discretion to design their own provisions. Appendix B provides detailed information on the elements of the index and its construction. We provide additional detail and examples from clawback provisions in Internet Appendix B. We classify a firm as a strong or a weak adopter according to whether its Clawback Strength Index lies above or below the yearly sample median of the index. Panel C of Table 1 shows that the Clawback Strength Index increases slightly over time for both strong and weak adopters.

We model the decision to adopt a strong clawback, a weak clawback, or no clawback through an ordered-logit model in the pre-adoption year. We then propensity-match strong adopters with weak adopters based on firm and governance characteristics. After excluding clawback firms with inconsistent clawback strength levels and missing firm and governance data, our sample for the propensity-score matching (PSM) consists of 743 unique clawback adopters (386 strong and 357 weak adopters), and 1,278 non-clawback adopters, representing a total of 5,328 firm-years in the matching equation. Panel D of Table 1 outlines the sample selection for the propensity-score matching in detail.

We obtain data on firms' governance and ownership structure from the Corporate Library and Thomson Reuters, data on executive compensation and CEO characteristics from ExecuComp, financial data from Compustat, and audit, financial restatement, and internal control weaknesses data from Audit Analytics. 


\subsection{Research design}

Our analysis compares changes in a sample of firms that have adopted strong clawbacks with a sample of control firms that have adopted a weak clawback. As in other studies that analyze voluntary adoptions of governance mechanisms, our findings may be influenced by omitted variables that are correlated with clawback strength and the outcome variables of interest (Armstrong et al., 2010; Roberts and Whited, 2013). We use several empirical techniques to deal with this concern.

First, we employ a DiD design between the pre- and post-adoption periods to explore changes in financial reporting quality, CEO turnover, and CEO pay for strong clawback adopters compared to weak clawback adopters. This approach mitigates concerns that unobserved time-invariant variables or market-wide factors drive the changes in our outcome variables.

Second, using a PSM method, we select strong and weak adopters for the DiD analysis. We estimate an ordered logistic propensityscore model to assess the probability that a firm will choose among the following three alternatives: (1) not adopting a clawback, (2) adopting a weak clawback, or (3) adopting a strong clawback. By doing so, we follow the assumption that firms understand the nature of clawbacks and therefore choose a specific clawback design. Drawing on the estimated probabilities, we obtain pairs of firms that have similar firm and governance characteristics prior to clawback adoption but that decide to adopt clawbacks with different strength levels.

To estimate the propensity-score model, we use several firm and governance characteristics that predict clawback adoption. deHaan et al. (2013) find, for example, that larger firms are more likely to adopt a clawback provision. Chan et al. (2012, 2015), and Chan et al. (2013) suggest that firm complexity, monitoring difficulties, and a firm's past restatement history are associated with clawback adoption. Iskandar-Datta and Jia (2013) find that firms' growth options are correlated with clawback adoption. These studies also suggest that governance characteristics may partly determine clawback adoption. Drawing on this literature, our propensity-score model includes proxies for size (total assets), complexity (R\&D, soft assets), monitoring (leverage, institutional ownership), current and past reporting quality (discretionary accruals, past restatement), growth opportunities (Tobin's Q), and corporate governance characteristics (audit committee size, board meetings, CEO chair, independent directors, insider ownership). We also include the following variables used in prior studies: cash return, change in receivables, loss, return on assets, return volatility, sales growth, and industry-fixed effects.

We estimate the following ordered logistic regression separately for each pre-adoption year:

$$
\begin{aligned}
& \operatorname{Pr}\left(\text { Clawbackstrength }_{i}\right)=\alpha+\beta_{1} \text { Audit committee size }_{i}+\beta_{2} \text { Board meetings }_{i} \\
& +\beta_{3} \text { Cash return }_{i}+\beta_{4} \text { CEO chair }{ }_{i}+\beta_{5} \text { Chg. receivables } i \\
& +\beta_{6} \text { Discretionary accruals }_{i}+\beta_{7} \text { Independent directors }_{i} \\
& +\beta_{8} \text { Insider ownership } p_{i}+\beta_{9} \text { Institutional ownership } p_{i} \\
& +\beta_{10} \text { Leverage }_{i}+\beta_{11} \text { Loss }_{i}+\beta_{12} \text { Past restatement }_{i} \\
& +\beta_{13} R \& D_{i}+\beta_{14} \text { Return on assets }{ }_{i}+\beta_{15} \text { Return volatility }_{i} \\
& +\beta_{16} \text { Sales growth }_{i}+\beta_{17} \text { Size }_{i}+\beta_{18} \text { Softassets }_{i} \\
& +\beta_{19} \text { Tobin's } Q_{i}+\Sigma \beta_{k} \text { Industry }+\varepsilon_{i}
\end{aligned}
$$

Clawback strength is an indicator variable equal to zero if the firm is a non-clawback adopter, one if the firm has adopted a weak clawback, and two if the firm has adopted a strong clawback. Appendix A provides variable definitions, and Panel A of Table 2 reports descriptive statistics of all variables employed in the matching equation.

Panel B of Table 2 reports the aggregated estimates of the ordered logistic regression. Column (2) reports the average coefficient estimate across year-specific estimations from 2007 through 2013. Column (3) reports an aggregated z-statistic, which is the sum of the individual annual z-statistic divided by the square root of the number of years for which we estimate the propensity-score model assuming independence over time. In column (4) we report the average marginal probability across all year-specific estimations. The last two columns report the number of years for which the year-specific coefficient is positive and negative, respectively.

We find that firm size, the percentage of independent directors, the number of audit committee members, and the percentage of institutional ownership are positively associated with clawback adoption and clawback strength. Furthermore, insider ownership and sales growth are negatively associated with clawback adoption and strength. The model has reasonable explanatory power, with an adjusted pseudo- $R^{2}$ of $25.59 \%$.

Next, we form matched pairs by selecting a firm that has adopted a strong clawback and another firm that has adopted a weak clawback. We use a matching procedure without replacement and require a maximum propensity-score difference (caliper) of 0.03 to decrease the likelihood of poor matches and to improve covariate balance (Shipman et al. 2017). The matching procedure results in 249 matched pairs of strong (treatment group) and weak adopters (control group). Panel C of Table 2 shows that the mean (median) difference in propensity-scores is $0.013(0.011)$.

We assess the covariate balance between the treatment and control groups and present the means (columns 1-2) and medians (columns 3-4) of our matching covariates in Panel D of Table 2. We conduct both a parametric $t$-test of the difference in means (column 5) and a non-parametric bootstrapped Kolmogorov-Smirnov (KS) test of the differences between two distributions (column 6). The two-tailed p-values show that we achieve covariate balance for all 19 covariates ( $p$-values $>0.10$ ). Following Jayaraman and Milbourn (2015), we also present the normalized differences in matching covariates (column 7). We calculate the normalized differences as the difference in means for the strong and weak adopter groups divided by the square root of the average of the group variances. Because all normalized differences are below the cutoff of 0.25 (as suggested by Imbens and Wooldridge, 2009), the 
Table 2

Propensity-score matching.

Panel A. Firm characteristics

\begin{tabular}{|c|c|c|c|c|c|c|c|c|}
\hline & \multicolumn{2}{|c|}{ Full sample } & \multicolumn{2}{|c|}{ No clawback } & \multicolumn{2}{|c|}{ Strong clawback } & \multicolumn{2}{|c|}{ Weak clawback } \\
\hline & Mean & SD & Mean & SD & Mean & SD & Mean & SD \\
\hline Audit committee size & 4.334 & 1.681 & 4.186 & 1.543 & 5.391 & 2.178 & 5.087 & 2.102 \\
\hline Board meetings & 7.737 & 3.532 & 7.660 & 3.550 & 8.220 & 3.434 & 8.207 & 3.325 \\
\hline Cash return & 0.102 & 0.201 & 0.096 & 0.209 & 0.133 & 0.131 & 0.145 & 0.131 \\
\hline CEO chair & 0.479 & 0.500 & 0.470 & 0.499 & 0.521 & 0.500 & 0.549 & 0.498 \\
\hline Chg. in acc. receivables & 0.009 & 0.042 & 0.010 & 0.042 & 0.004 & 0.037 & 0.011 & 0.039 \\
\hline Discretionary accruals & 0.083 & 0.119 & 0.085 & 0.120 & 0.071 & 0.117 & 0.069 & 0.103 \\
\hline Independent directors & 0.708 & 0.100 & 0.701 & 0.099 & 0.753 & 0.084 & 0.748 & 0.095 \\
\hline Insider ownership & 0.207 & 0.226 & 0.224 & 0.231 & 0.092 & 0.151 & 0.106 & 0.155 \\
\hline Institutional ownership & 0.703 & 0.258 & 0.687 & 0.262 & 0.808 & 0.193 & 0.804 & 0.202 \\
\hline Leverage & 0.186 & 0.222 & 0.180 & 0.227 & 0.234 & 0.186 & 0.216 & 0.189 \\
\hline Loss & 0.298 & 0.457 & 0.318 & 0.466 & 0.153 & 0.360 & 0.202 & 0.402 \\
\hline Past restatement & 0.066 & 0.248 & 0.065 & 0.247 & 0.060 & 0.237 & 0.076 & 0.265 \\
\hline $\mathrm{R} \& \mathrm{D}$ & 0.292 & 1.370 & 0.317 & 1.422 & 0.178 & 1.164 & 0.099 & 0.711 \\
\hline Return on assets & -0.007 & 0.198 & -0.013 & 0.206 & 0.029 & 0.140 & 0.032 & 0.139 \\
\hline Return volatility & 0.033 & 0.015 & 0.034 & 0.015 & 0.028 & 0.014 & 0.028 & 0.012 \\
\hline Sales growth & 0.144 & 0.449 & 0.152 & 0.468 & 0.071 & 0.293 & 0.121 & 0.308 \\
\hline Size & 6.278 & 1.385 & 6.054 & 1.214 & 7.703 & 1.504 & 7.612 & 1.629 \\
\hline Soft assets & 0.513 & 0.241 & 0.506 & 0.242 & 0.571 & 0.235 & 0.549 & 0.231 \\
\hline Tobin's Q & 1.994 & 1.496 & 2.032 & 1.526 & 1.730 & 1.228 & 1.791 & 1.308 \\
\hline Number of observations & 5,328 & & 4,585 & & 386 & & 357 & \\
\hline
\end{tabular}

Panel B: Propensity-score estimation using ordered logistic regression

\begin{tabular}{|c|c|c|c|c|c|c|}
\hline & $\begin{array}{l}\text { (1) Predicted } \\
\text { Sign }\end{array}$ & $\begin{array}{l}\text { (2) Average } \\
\text { coefficient }\end{array}$ & $\begin{array}{l}\text { (3) Aggregate z- } \\
\text { statistic }\end{array}$ & $\begin{array}{l}\text { (4) Average marg. } \\
\text { prob. }\end{array}$ & $\begin{array}{l}\text { (5) Years with } \\
\text { pos. coef. }\end{array}$ & $\begin{array}{l}\text { (6) Years with } \\
\text { neg. coef. }\end{array}$ \\
\hline Audit committee size & + & $0.759^{* * *}$ & 4.04 & 0.049 & 6 & 1 \\
\hline Board meetings & + & $0.380^{* * * *}$ & 2.85 & 0.020 & 7 & 0 \\
\hline Cash return & - & -0.406 & -0.97 & -0.034 & 2 & 5 \\
\hline CEO chair & - & 0.135 & 1.32 & 0.008 & 6 & 1 \\
\hline Chg. in acc. receivables & - & -0.739 & -0.65 & 0.022 & 3 & 4 \\
\hline Discretionary accruals & + & 0.326 & 1.10 & 0.040 & 4 & 3 \\
\hline Independent directors & + & $2.323^{* * *}$ & 4.14 & 0.131 & 7 & 0 \\
\hline Insider ownership & - & $-2.556 * * *$ & -7.91 & -0.155 & 0 & 7 \\
\hline Institutional ownership & + & $0.560 * *$ & 2.32 & 0.036 & 7 & 0 \\
\hline Leverage & - & $-0.767 * * *$ & -3.07 & -0.039 & 1 & 6 \\
\hline Loss & - & $-0.381 * *$ & -2.25 & -0.020 & 0 & 7 \\
\hline Past restatement & + & 0.025 & 0.50 & 0.007 & 4 & 3 \\
\hline $\mathrm{R} \& \mathrm{D}$ & - & -0.320 & -1.29 & -0.015 & 2 & 5 \\
\hline Return on assets & + & -0.043 & -1.31 & 0.003 & 2 & 5 \\
\hline Return volatility & + & 7.083 & 0.72 & 0.404 & 4 & 3 \\
\hline Sales growth & - & $-0.734^{* * *}$ & -2.84 & -0.037 & 1 & 6 \\
\hline Size & + & $0.807 * * *$ & 19.88 & 0.045 & 7 & 0 \\
\hline Soft assets & + & $0.904^{* * *}$ & 3.86 & 0.051 & 7 & 0 \\
\hline Tobin's Q & + & 0.023 & 0.49 & 0.001 & 4 & 3 \\
\hline $\begin{array}{l}\text { Intercept No clawback } \rightarrow \text { Weak } \\
\quad \text { clawback }\end{array}$ & + & $11.735^{* * * *}$ & 15.93 & & 7 & 0 \\
\hline $\begin{array}{l}\text { Intercept Weak clawback } \rightarrow \\
\quad \text { Strong clawback }\end{array}$ & + & $12.748^{* * *}$ & 17.19 & & 7 & 0 \\
\hline Industry fixed effects & & Yes & & & & \\
\hline Observations (over all years) & & 5,328 & & & & \\
\hline Adjusted Pseudo- $R^{2}$ & & $25.59 \%$ & & & & \\
\hline
\end{tabular}

Panel C: Differences in propensity scores for matched pairs

\begin{tabular}{llllll} 
& Matched pairs & Mean & Std. dev. & Min. & Median \\
\hline Strong vs. Weak & 249 & 0.013 & 0.009 & 0.000 & 0.011 \\
\hline
\end{tabular}

Panel D: Covariate balance between the matched pairs of 249 strong and 249 weak clawback adopters

\begin{tabular}{llllllll}
\hline & $\begin{array}{l}\text { (1) Mean } \\
\text { strong }\end{array}$ & $\begin{array}{l}\text { (2) Mean } \\
\text { weak }\end{array}$ & $\begin{array}{l}\text { (3) Median } \\
\text { strong }\end{array}$ & $\begin{array}{l}\text { (4) Median } \\
\text { weak }\end{array}$ & $\begin{array}{l}\text { (5) } t \text {-test difference } \\
\text { p-value }\end{array}$ & $\begin{array}{l}\text { (6) KS bootstrap } \\
\text { difference p-value }\end{array}$ & $\begin{array}{l}\text { (7) Norm. } \\
\text { difference }\end{array}$ \\
\hline Audit committee size & 5.265 & 5.201 & 5.000 & 5.000 & 0.738 & 1.000 & 0.030 \\
(continued on next page)
\end{tabular}


Table 2 (continued)

Panel D: Covariate balance between the matched pairs of 249 strong and 249 weak clawback adopters

\begin{tabular}{|c|c|c|c|c|c|c|c|}
\hline Board meetings & 8.072 & 8.434 & 7.000 & 8.000 & 0.247 & 0.935 & -0.104 \\
\hline Cash return & 0.133 & 0.141 & 0.139 & 0.129 & 0.519 & 0.887 & -0.058 \\
\hline CEO chair & 0.526 & 0.534 & 1.000 & 1.000 & 0.858 & 1.000 & -0.016 \\
\hline Chg. in acc. receivables & 0.006 & 0.010 & 0.005 & 0.006 & 0.245 & 0.607 & -0.104 \\
\hline Discretionary accruals & 0.077 & 0.065 & 0.035 & 0.034 & 0.260 & 0.757 & 0.101 \\
\hline Independent directors & 0.747 & 0.757 & 0.750 & 0.769 & 0.234 & 0.286 & -0.107 \\
\hline Insider ownership & 0.103 & 0.092 & 0.040 & 0.041 & 0.429 & 0.935 & 0.071 \\
\hline Institutional ownership & 0.823 & 0.820 & 0.846 & 0.841 & 0.859 & 0.757 & 0.016 \\
\hline Leverage & 0.226 & 0.228 & 0.214 & 0.204 & 0.920 & 0.398 & -0.009 \\
\hline Loss & 0.173 & 0.197 & 0.000 & 0.000 & 0.489 & 1.000 & -0.062 \\
\hline Past restatement & 0.056 & 0.076 & 0.000 & 0.000 & 0.369 & 1.000 & -0.081 \\
\hline$R \& D$ & 0.202 & 0.117 & 0.002 & 0.000 & 0.363 & 0.198 & 0.082 \\
\hline Return on assets & 0.025 & 0.032 & 0.050 & 0.046 & 0.572 & 0.533 & -0.051 \\
\hline Return volatility & 0.028 & 0.028 & 0.025 & 0.026 & 0.763 & 0.887 & -0.027 \\
\hline Sales growth & 0.093 & 0.122 & 0.072 & 0.091 & 0.338 & 0.286 & -0.086 \\
\hline Size & 7.610 & 7.760 & 7.495 & 7.520 & 0.265 & 0.463 & -0.100 \\
\hline Soft assets & 0.568 & 0.541 & 0.616 & 0.568 & 0.211 & 0.107 & 0.112 \\
\hline Tobin's Q & 1.750 & 1.777 & 1.409 & 1.320 & 0.812 & 0.162 & -0.021 \\
\hline
\end{tabular}

This table Panel A reports descriptive statistics on all firm characteristics employed in the propensity-score matching. Panel B reports the results of the propensity-match ordered logit model. The ordered logit regressions are run separately for each year. All variables are measured in the year prior to clawback adoption. The first column provides the predicted signs of the variables. Column (2) reports the average coefficient estimate across yearspecific estimation from 2007 through 2013. Column (3) reports an aggregated z-statistic, which is calculated as the sum of the individual annual zstatistic divided by the square root of the number of years for which the propensity score model is estimated. This aggregated z-statistic assumes that each annual estimation is independent of the other estimations. Column (4) reports the average marginal probability across year-specific estimations. Columns (5) and (6) report the number of years for which the year-specific coefficient is positive and negative, respectively. Adj. Pseudo $\mathrm{R}^{2}$ is the average McFadden's [2000] adjusted pseudo $\mathrm{R}^{2}$. Standard errors are adjusted based on the Huber-White sandwich estimate of variances. Panel C presents statistics on the differences in propensity-scores between matched pairs of strong and weak clawback adopters. Panel D presents the test statistics of covariate distributions for strong clawback adopters and weak clawback adopters. We show the p-values for a parametric $t$-test of the difference in means in column (5) and a non-parametric Kolmogorov-Smirnov (KS) test of the difference between two distributions in column (6). We bootstrap the KS-test with 2,000 bootstrap samples following Sekhon (2009). We also report normalized differences to assess the economic significance of reported differences in column (7). Normalized differences indicate the difference in means for strong and weak adopter groups divided by the square root of the average of the group variances. A normalized difference of 0.25 or less indicates an acceptable balance (Imbens and Wooldridge, 2009). Continuous variables are winsorized at $1 \%$ and $99 \%$ and all variables are described in Appendix A. ***, **, * denote significance at the $1 \%, 5 \%$, and $10 \%$ level.

economic differences in covariates between the two groups are negligible. Overall, both tests suggest that our estimates of the average treatment effect are unlikely to be confounded by differences in covariates across the two groups.

We next use our matched firm pairs of strong and weak clawback adopters in a DiD design to study changes in financial reporting quality, CEO turnover, and CEO pay. Our base model for testing each of our hypotheses is as follows:

$$
\begin{aligned}
& \text { Outcome variable }_{i t}=\alpha_{1}+\beta_{1} \text { Strong }_{\text {clawback }}+\beta_{2} \text { After }_{i t} \\
& +\beta_{3} \text { Strong clawback }_{i} \text { After }_{i t}+\Sigma \beta_{k} \text { Control variables }_{i t} \\
& +\Sigma \beta_{f}(\text { Industry, Year })+\varepsilon_{i t},
\end{aligned}
$$

where the Outcome variable is the consequence under study (reporting quality, CEO turnover, CEO pay). Strong clawback equals one if the firm has adopted a strong clawback, and zero if it has adopted a weak clawback. After equals one for firm-years after adoption and zero for firm-years before adoption. Strong clawback $\times$ After is the interaction term of Strong clawback and After. The coefficient $\beta_{1}$ captures the difference between the two groups before clawback adoption. The coefficient $\beta_{2}$ captures the time trend for the control group of weak adopters. $\beta_{3}$, our coefficient of interest, is the DiD estimator for the outcome variable following the adoption of strong versus weak clawbacks. It captures the incremental effect of adopting a strong clawback, relative to before the adoption and compared to firms adopting a weak clawback.

Depending on the outcome measure under study, we include different sets of control variables. To ensure reliable before and after adoption analyses, we require the availability of at least two years of pre- and post-adoption period data. All continuous variables are winsorized at the top and bottom $1 \%$ of the distribution. Factors such as asset structure, accounting practices, government regulation, and industry competition may vary across industries. To account for these differences, we include indicator variables based on FamaFrench industry classification codes in all models. To control for macroeconomic effects, we also include year fixed effects. We use standard errors clustered on both firm and time (Gow et al., 2010). In Panel A of Table A1 of the Appendix, we provide descriptive statistics for all firm characteristics employed in our regressions on reporting quality (column 1), CEO turnover, and CEO pay (column 2). 


\section{Results}

\subsection{Clawback strength and financial reporting quality}

We first test whether clawback strength affects reporting quality (H1). More specifically, we examine whether clawback strength changes the likelihood of misstatements and restatements. Misstatement is an indicator variable that equals one for fiscal years with a restatement and zero otherwise. Restatement is an indicator variable that equals one for the first fiscal year in which improper accounting later necessitated a restatement, and zero otherwise.

The univariate test statistics reported in Table 3, Panel A, show that strong adopters have a significant decline in misstatement rates from the pre- to the post-adoption period, while weak adopters have an insignificant increase over the same period. Consequently, the DiD between strong and weak adopters is negative and highly significant $(-8.41 \%$; p-value $<0.01)$. We obtain qualitatively similar results for restatements $(-3.71 \%$; $p$-value $<0.01)$.

Next, we estimate equation (Eq. (2)) using a logit model with Misstatement and Restatement as the dependent variables. We include the same set of control variables as in the propensity-score model. Panel B of Table 3 presents the multivariate results. The coefficient estimates confirm our findings of the univariate analyses. Although we find no systematic differences in misstatement or restatement rates between strong and weak clawback adopters before clawback adoption, we find a (marginally significant) positive time trend in restatement rates for both strong and weak adopters. Most importantly, the DiD estimator Strong clawback $\times$ After is negative and highly significant in both the Misstatement and the Restatement equations ( $p$-values $<0.01$ and $<0.05$, respectively). Evaluated at the means, the $\beta_{3}$ coefficient demonstrates a $10.2 \%(5.8 \%)$ reduction in the probability of a misstatement (restatement) for strong clawback adopters compared to weak clawback adopters, between the pre- and post-periods. The sign of most control variables is in line with prior research. For example, more levered and more complex firms have a lower financial reporting quality, whereas profitability is positively associated with reporting quality.

However, these findings may reflect executives' reluctance to file a restatement, instead of real improvements in reporting quality. We deal with this concern by using six alternative measures of reporting quality employed in prior studies (Chan et al., 2012; deHaan et al., 2013) that do not rely on restatements. First, we examine the disclosure of internal control weaknesses under SOX 302 and SOX 404 as an indicator for the effectiveness of a firm's internal reporting process. Studies have shown that effective internal controls are associated with reporting quality (e.g., Ashbaugh-Skaife et al., 2007; Doyle et al., 2007). We estimate equation (Eq. (2)) with a logit model and employ the same covariates and sample as in the Mistatement and Restatement analyses. The dependent variable is either SOX 302 or SOX 404. SOX 302 equals one if a firm has disclosed material internal control weaknesses and zero otherwise. SOX 404 equals one if a firm's independent auditor has identified material internal control weaknesses and zero otherwise.

Second, we study total Audit fees and Unexplained audit fees to proxy for auditors' perception of the firms' reporting quality and the demand for monitoring of the financial reporting process. Total annual audit fees capture the firm-specific and environmental forces that can impact the overall transparency and riskiness of the financial reporting process (Engel et al., 2010). In line with Hribar et al. (2014), unexplained audit fees capture the auditor's legal and reputational costs associated with misstatements priced in audit fees. We calculate Unexplained audit fees as the residual obtained from regressions of audit fees on a set of determinants. We estimate equation (Eq. (2)) with an OLS model and use the natural logarithm of Audit fees, and Unexplained audit fees as dependent variables. Descriptive statistics for all covariates used in these regressions are provided in column (1) in Panel B of Table A1 in the Internet Appendix.

Third, we analyze a firm's meet/beat behavior. Observing a discontinuity of earnings distributions around analyst forecasts is considered evidence of earnings management and financial statement manipulation (e.g., Graham et al., 2005; Burgstahler and Chuk, 2015). We estimate equation (Eq. (2)) with quarterly data using a logit model and Meet/Beat as the outcome variable. Meet/Beat is equal to one if the firm has either no or a USD 0.01 deviation from the median of analyst earnings per share consensus forecast each quarter, and zero otherwise.

Fourth, we examine the stock market perception of firms' earnings quality. We study the market reaction on quarterly earnings surprises around clawback adoption (earnings response coefficient, ERC). Higher ERC magnitudes are positively associated with investors' assessment of reporting quality (Liu and Thomas, 2000). We present the descriptive statistics for all covariates employed in the analyses of a firm's meet/beat behavior and its earnings response coefficients in column (2) in Panel B of Table A1 in the Internet Appendix.

Panel C of Table 3 presents the results of all additional tests. In all tests, we find that strong clawback adopters, compared to weak clawback adopters, significantly improve their reporting quality, between the pre- and post-periods. In sum, our findings imply that both auditors and investors perceive an improvement in firms' financial statement quality following the adoption of a strong clawback. This finding suggests that our main results are evidence of real improvements in reporting quality.

Both the univariate and multivariate results are consistent with our predictions. However, the interpretation of the improvements in reporting quality is not straightforward. Under the isolated clawback explanation, a strong clawback increases the out-of-pocket costs for CEOs following an accounting restatement. These costs, in addition to a potential dismissal, may prod executives to improve reporting quality. Under the broader reform explanation, a strong clawback is part of a larger set of within-firm changes for reducing overall reporting risk. This explanation suggests that our results reflect the effect of a larger set of changes, not the purely causal effect of the strong clawback. Viewed collectively, all our findings suggest that firms adopt weak clawbacks for window-dressing purposes. 
Table 3

Effect of clawback strength on reporting quality.

Panel A: Univariate tests for the effect of clawback strength on misstatements and restatements

\begin{tabular}{|c|c|c|c|c|c|c|c|}
\hline & & \multicolumn{3}{|c|}{ (1) Misstatement (in \%) } & \multicolumn{3}{|c|}{ (2) Restatement (in \%) } \\
\hline & $\mathrm{N}$ & 1,677 & 1,258 & 2,935 & 1,677 & 1,258 & 2,935 \\
\hline Strong clawback & 1,474 & 10.68 & 4.50 & $-6.18^{* * *}$ & 4.93 & 1.61 & $-3.32^{* * *}$ \\
\hline Weak clawback & 1,461 & 12.24 & 14.47 & 2.23 & 5.58 & 5.97 & 0.39 \\
\hline $\begin{array}{l}\Delta \text { (Strong - Weak) } \\
\text { Rosenbaum } \Gamma\end{array}$ & 2,935 & -1.56 & $-9.97 * * *$ & $\begin{array}{l}-8.41^{* * *} \\
1.63\end{array}$ & -0.65 & $-4.36^{* * *}$ & $\begin{array}{l}-3.71 * * * \\
2.31\end{array}$ \\
\hline
\end{tabular}

Panel B: Multivariate tests for the effect of clawback strength on misstatements and restatements

\begin{tabular}{|c|c|c|c|c|}
\hline & \multicolumn{2}{|c|}{ (1) Misstatement } & \multicolumn{2}{|c|}{ (2) Restatement } \\
\hline & Coef. & Marg. prob. & Coef. & Marg. prob. \\
\hline Strong clawback & $\begin{array}{l}-0.228 \\
(-0.96)\end{array}$ & -0.020 & $\begin{array}{l}-0.116 \\
(-0.45)\end{array}$ & -0.005 \\
\hline After & $\begin{array}{l}0.317 \\
(1.54)\end{array}$ & 0.028 & $\begin{array}{l}0.389^{*} \\
(1.88)\end{array}$ & 0.016 \\
\hline Strong clawback $\times$ After & $\begin{array}{l}-1.169^{* * *} \\
(-3.34)\end{array}$ & -0.102 & $\begin{array}{l}-1.374^{* *} \\
(-2.51)\end{array}$ & -0.058 \\
\hline Audit committee size & $\begin{array}{l}0.077 \\
(1.49)\end{array}$ & 0.007 & $\begin{array}{l}0.163^{* *} \\
(2.17)\end{array}$ & 0.007 \\
\hline Board meetings & $\begin{array}{l}-0.035 \\
(-1.54)\end{array}$ & -0.003 & $\begin{array}{l}-0.043 \\
(-1.50)\end{array}$ & -0.002 \\
\hline Cash return & $\begin{array}{l}-0.117 \\
(-0.13)\end{array}$ & -0.010 & $\begin{array}{l}2.947^{*} \\
(1.87)\end{array}$ & 0.124 \\
\hline CEO chair & $\begin{array}{l}-0.303^{*} \\
(-1.84)\end{array}$ & -0.026 & $\begin{array}{l}-0.045 \\
(-0.41)\end{array}$ & -0.002 \\
\hline Chg. in acc. receivables & $\begin{array}{l}0.001 \\
(1.06)\end{array}$ & 0.000 & $\begin{array}{l}0.001 \\
(0.61)\end{array}$ & 0.000 \\
\hline Discretionary accruals & $\begin{array}{l}0.08 \\
(0.14)\end{array}$ & 0.007 & $\begin{array}{l}-0.519 \\
(-0.47)\end{array}$ & -0.022 \\
\hline Independent directors & $\begin{array}{l}-0.957 \\
(-0.86)\end{array}$ & -0.084 & $\begin{array}{l}-2.425^{* *} \\
(-2.48)\end{array}$ & -0.102 \\
\hline Insider ownership & $\begin{array}{l}0.743 \\
(1.33)\end{array}$ & 0.065 & $\begin{array}{l}0.513 \\
(0.85)\end{array}$ & 0.022 \\
\hline Institutional ownership & $\begin{array}{l}0.256 \\
(0.36)\end{array}$ & 0.022 & $\begin{array}{l}0.164 \\
(0.30)\end{array}$ & 0.007 \\
\hline Leverage & $\begin{array}{l}1.234^{* * *} \\
(3.19)\end{array}$ & 0.108 & $\begin{array}{l}1.615^{* * *} \\
(3.25)\end{array}$ & 0.068 \\
\hline Loss & $\begin{array}{l}-0.165 \\
(-0.76)\end{array}$ & -0.014 & $\begin{array}{l}0.353 \\
(1.20)\end{array}$ & 0.015 \\
\hline R\&D & $\begin{array}{l}0.748^{* * *} \\
(3.33)\end{array}$ & 0.065 & $\begin{array}{l}0.617^{* * * *} \\
(2.66)\end{array}$ & 0.026 \\
\hline Past restatement & $\begin{array}{l}0.093 \\
(0.62)\end{array}$ & 0.008 & $\begin{array}{l}0.126 \\
(0.86)\end{array}$ & 0.005 \\
\hline Return on assets & $\begin{array}{l}-1.742^{* * *} \\
(-4.29)\end{array}$ & -0.152 & $\begin{array}{l}-2.741^{* * *} \\
(-4.02)\end{array}$ & -0.115 \\
\hline Return volatility & $\begin{array}{l}7.583 \\
(0.60)\end{array}$ & 0.663 & $\begin{array}{l}-0.236 \\
(-0.01)\end{array}$ & -0.010 \\
\hline Sales growth & $\begin{array}{l}0.043 \\
(0.61)\end{array}$ & 0.004 & $\begin{array}{l}0.126 \\
(1.57)\end{array}$ & 0.005 \\
\hline Size & $\begin{array}{l}-0.124 \\
(-1.46)\end{array}$ & -0.011 & $\begin{array}{l}-0.175 \\
(-1.40)\end{array}$ & -0.007 \\
\hline Soft assets & $\begin{array}{l}0.246 \\
(0.52)\end{array}$ & 0.022 & $\begin{array}{l}-0.339 \\
(-0.91)\end{array}$ & -0.014 \\
\hline Tobin's Q & $\begin{array}{l}-0.178^{*} \\
(-1.73)\end{array}$ & -0.016 & $\begin{array}{l}-0.273^{*} \\
(-1.76)\end{array}$ & -0.011 \\
\hline Constant & $\begin{array}{l}-1.042 \\
(-0.94)\end{array}$ & & $\begin{array}{l}-2.083^{*} \\
(-1.76)\end{array}$ & \\
\hline
\end{tabular}


Table 3 (continued)

Panel B: Multivariate tests for the effect of clawback strength on misstatements and restatements

\begin{tabular}{lll}
\hline Observations & 2,935 & 2,935 \\
Pseudo $R^{2}$ & $10.40 \%$ & $10.60 \%$ \\
\hline
\end{tabular}

Panel C: Multivariate tests for the effect of clawback strength on other reporting quality measures

\begin{tabular}{|c|c|c|c|c|c|c|}
\hline & SOX 302 & SOX 404 & Audit fees & Unexplained audit fees & Meet/ beat & $E R C$ \\
\hline Strong clawback & $\begin{array}{l}0.105 \\
(1.52)\end{array}$ & $\begin{array}{l}0.410 \\
(0.96)\end{array}$ & $\begin{array}{l}-0.003 \\
(-0.09)\end{array}$ & $\begin{array}{l}-0.003 \\
(-0.08)\end{array}$ & $\begin{array}{l}0.112 \\
(1.42)\end{array}$ & $\begin{array}{l}0.001 \\
(0.45)\end{array}$ \\
\hline After & $\begin{array}{l}0.077 \\
(0.45)\end{array}$ & $\begin{array}{l}-0.267 \\
(-1.30)\end{array}$ & $\begin{array}{l}0.052 \\
(1.76)\end{array}$ & $\begin{array}{l}0.045 \\
(1.46)\end{array}$ & $\begin{array}{l}0.168 \\
(1.51)\end{array}$ & $\begin{array}{l}0.004^{* *} \\
(2.01)\end{array}$ \\
\hline Strong clawback $\times$ After & $\begin{array}{l}-0.390 * * \\
(-2.18)\end{array}$ & $\begin{array}{l}-0.901 \% \\
(-1.77)\end{array}$ & $\begin{array}{l}-0.027^{*} \\
(-1.84)\end{array}$ & $\begin{array}{l}-0.042^{* *} \\
(-2.03)\end{array}$ & $\begin{array}{l}-0.160 * * \\
(-2.34)\end{array}$ & $\begin{array}{l}-0.006 \\
(-1.56)\end{array}$ \\
\hline Earnings surprise (ES) & & & & & & $\begin{array}{l}0.770 * * * \\
(3.25)\end{array}$ \\
\hline ES $\times$ Str. claw. $\times$ After & & & & & & $\begin{array}{l}1.095^{* * *} \\
(2.71)\end{array}$ \\
\hline $\mathrm{ES} \times$ Strong clawback & & & & & & $\begin{array}{l}-0.393 \\
(-1.39)\end{array}$ \\
\hline ES $\times$ After & & & & & & $\begin{array}{l}-0.108 \\
(-0.56)\end{array}$ \\
\hline Controls and year/quarter \& industry fixed effects & yes & yes & yes & yes & yes & yes \\
\hline Observations & 2,935 & 2,935 & 3,367 & 3,315 & 6,479 & 6,349 \\
\hline Pseudo/Adjusted $R^{2}$ & $7.49 \%$ & $15.80 \%$ & $79.95 \%$ & $11.30 \%$ & $13.30 \%$ & $7.50 \%$ \\
\hline
\end{tabular}

This table presents tests for adopting strong vs. weak clawbacks on financial reporting quality measures. Strong adopters are propensity-matched to weak adopters, resulting in 249 matched pairs. Panel A reports univariate two-tailed test statistics for differences in means on the likelihood of accounting misstatements and restatements based on the sample used in the multivariate analysis. We require the availability of at least two years of pre- and post-adoption data. We also report, when applicable, the Rosenbaum $\Gamma$ to quantify the amount of hidden bias necessary to alter the statistical significance $(p=0.10)$ in univariate tests that results from the assumption that two observations with identical propensity scores have an equal probability of receiving treatment. Panel B presents multivariate tests (Logit regressions). Panel C analyzes further proxies for reporting quality. In logit regressions on SOX 302 and SOX 404 we use the same control variables as in our regressions on misstatements and restatements. In OLS regressions on (unexplained) audit fees we include the following control variables: audit committee size, BIG4, board meetings, cash return, current ratio, debt issuance, discretionary accruals, extraordinary items, foreign sales, independent directors, insider ownership, institutional ownership, inventory, leverage, loss, past restatement, receivables, R\&D, return on assets, return volatility, sales growth, seasoned equity offerings (SEO), size, and Tobin's q. In the Logit [OLS] regressions on Meet/Beat frequency [two-days cumulative abnormal returns around quarterly earnings announcements] we use quarterly data and control for the following factors: Altman z-score, [only in regression on meet/beat frequency: audit committee size], [board meetings], book-to-market, cash return, capital intensity, [CEO chair], discretionary accruals, downward revision, earnings growth, [earnings surprise], fourth fiscal quarter, [independent directors], [insider ownership], [institutional ownership], leverage, loss, nonlinear median estimate, number of estimates, past meet/beat, past restatement, return on assets, return volatility, sales growth, size, shares outstanding, soft assets, and write-offs. We refer to Table A4 in the Internet Appendix for descriptive statistics of all covariates employed in our regressions. Continuous variables are winsorized at $1 \%$ and $99 \%$ and all variables are described in Appendix A. Standard errors are robust to clustering at the year- and firm-level. Z-/T-values are in parentheses. ***, **, * denote significance at the $1 \%, 5 \%$, and $10 \%$ level.

\subsection{Clawback strength and CEO turnover}

We next examine whether clawback strength has an impact on CEO turnover (H2). Column (1) in Panel A of Table 4 presents the univariate test statistics. We find that turnover rates significantly decrease from the pre- to the post-adoption period for strong clawback adopters $(-3.89 \%, p$-value $<0.05)$, while they remain relatively stable for weak adopters $(-0.34 \%, p$-value $>0.10)$. Consequently, the DiD between strong and weak adopters and between the pre- and post-periods is significantly negative $(-3.55 \%, p$-value $<0.05)$.

We find similar results in a multivariate setting. In addition to the set of covariates used in the propensity-score model, we control for CEO age, Share return, and Underperformance. Column (1) in Panel B of Table 4 presents the multivariate results and shows a significantly negative coefficient on Strong clawback $\times$ After ( $p$-value $<0.01$ ). Evaluated at the means, the marginal probability for the likelihood of a CEO turnover is $4.0 \%$ lower for strong adopters than for weak adopters, between the pre- and post-adoption periods.

These results are consistent with our predictions for reporting quality (H1). A potential compensation recoupment increases the costs to CEOs if they are dismissed following accounting manipulations. As these costs are higher for strong clawbacks than for weak clawbacks, strong clawbacks are more effective in motivating CEOs to report truthfully and are thus associated with fewer turnovers.

\subsection{Clawback strength and CEO pay}

We now explore whether clawback strength has an impact on CEO pay (H3). We measure CEO pay using the natural logarithms of CEO total pay, CEO non-incentive pay (the sum of salary and other compensation), and CEO incentive pay (the sum of bonus, options, grants, and non-equity incentive pay). 
Table 4

Effect of clawback strength on CEO turnover and CEO pay.

Panel A: Univariate tests for the effect of clawback strength on CEO turnover and CEO pay

\begin{tabular}{|c|c|c|c|c|c|c|c|}
\hline & & \multicolumn{3}{|c|}{ (1) CEO turnover (in \%) } & \multicolumn{3}{|l|}{ (2) CEO total pay } \\
\hline & $\mathrm{N}$ & 1,355 & 1,086 & 2,441 & 1,355 & 1,086 & 2,441 \\
\hline Strong clawback & 1,217 & 11.97 & 8.08 & $-3.89 * *$ & 8.28 & 8.56 & $0.27 * * *$ \\
\hline Weak clawback & 1,224 & 10.45 & 10.11 & -0.34 & 8.18 & 8.62 & $0.45^{* * *}$ \\
\hline$\Delta$ (Strong - Weak) & 2,441 & 1.52 & -2.03 & $-3.55^{* *}$ & $0.11^{*}$ & -0.07 & $-0.18^{* *}$ \\
\hline \multirow[t]{2}{*}{ Rosenbaum $\Gamma$} & & & 1.43 & & & 1.37 & \\
\hline & & \multicolumn{3}{|c|}{ (3) CEO non-incentive pay } & \multicolumn{3}{|c|}{ (4) $C E O$ incentive pay } \\
\hline Strong clawback & 1,217 & 6.77 & 6.93 & $0.16^{* * *}$ & 7.85 & 8.22 & $0.38^{* * *}$ \\
\hline Weak clawback & 1,224 & 6.74 & 6.95 & $0.21 * * *$ & 7.61 & 8.25 & $0.64 * * *$ \\
\hline$\Delta$ (Strong - Weak) & 2,441 & 0.03 & -0.02 & -0.05 & $0.24 * *$ & -0.02 & $-0.26^{* *}$ \\
\hline Rosenbaum $\Gamma$ & & & n.a. & & & 1.29 & \\
\hline
\end{tabular}

Panel B: Multivariate tests for the effect of clawback strength on CEO turnover and compensation

$\begin{array}{ll}\text { (1) CEO turnover } & \text { (2) CEO total pay }\end{array}$

Coef.

Strong clawback

After

Strong clawback $\times$ After

Audit committee size

Board meetings

Cash flow

CEO age

CEO chair

CEO tenure

Chg. In acc. receivables

Discretionary accruals

Independent directors

Insider ownership

Institutional ownership

Leverage

Loss

Past restatement

Return on assets

Return volatility

Sales growth

Size

Share return

Soft assets

Tobin's Q

Underperformance

0.237
$(1.55)$
-0.096
$(-0.43)$
$-0.495^{* * *}$
$(-2.69)$
0.060
$(0.90)$
$0.061^{*}$
$(1.87)$
1.023
$(0.91)$
$-0.072^{* * *}$
$(-4.53)$
$-1.289^{* * *}$
$(-7.41)$

$-0.001$

$(-1.03)$

0.167

(0.15)

$-2.063^{* * *}$

$(-3.92)$

0.039

(0.04)

$-0.333$

$(-0.63)$

0.299

(0.71)

0.304

(0.98)

0.145

(1.04)

$-2.070 * * *$

$(-3.77)$

1.656

(0.13)

$-0.838$

$(-0.81)$

0.108

(1.34)

$-0.008$

$(-0.49)$

$-0.459$

$(-0.86)$

0.002

(0.02)

0.317 *
Marg. Prob.

$\begin{array}{ll}0.019 & 0.078 \\ & (0.96) \\ -0.008 & 0.165 \\ & (1.46) \\ -0.040 & -\mathbf{0 . 1 7 5 * *} \\ & (-2.05) \\ 0.005 & -0.001 \\ & (-0.02) \\ 0.005 & 0.007 \\ & (0.62) \\ 0.082 & -1.604 \\ & (-0.76)\end{array}$

$-0.006$

$-0.104$

0.071

(1.21)

0.048 *

(1.84)

$-0.000$

$-0.002$

$(-1.61)$

0.013

0.073

(0.53)

$-0.166$

0.080

(0.23)

0.003

$-0.361$

$(-1.44)$

$-0.027$

0.510 **

(2.30)

0.024

$-0.155$

$(-0.70)$

0.025

0.012

$-0.167$

0.133

$-0.068$

0.009

$-0.001$

$-0.037$

0.000

$-0.059$

$(-0.48)$

$-0.092$

$(-1.01)$

2.017

(0.94)

$-2.142$

$(-0.66)$

0.036

(1.09)

0.389 ***

(8.70)

$0.004 * * *$

(5.19)

0.240

(1.14)

$0.086^{* *}$

(2.27)

$-0.114^{* * *}$
(3) CEO non-incentive pay

(4) CEO incentive pay

$\begin{array}{ll}-0.017 & 0.181 \\ (-0.35) & (1.35) \\ 0.051 & 0.204 \\ (0.60) & (1.61) \\ -0.015 & -0.239 * * \\ (-0.24) & (-1.98) \\ 0.014 & -0.029 \\ (0.85) & (-1.10) \\ 0.001 & 0.015 \\ (0.11) & (1.17) \\ -2.491 * & -1.655 \\ (-1.76) & (-0.60)\end{array}$

$-0.028$

$(-0.51)$

$0.095^{* * *}$

(4.22)

$-0.001$

$(-1.33)$

$-0.035$

$(-0.27)$

0.537 **

(2.13)

$-0.084$

$(-0.35)$

0.060

(0.39)

$-0.013$

$(-0.09)$

$-0.136^{*}$

$(-1.74)$

$-0.090$

$(-1.61)$

(2.16)

$-2.949$

(-1.36)

$-0.032$

$(-0.53)$

0.159 ***

(5.72)

$0.002 * * *$

(3.86)

0.317 **

(2.13)

$-0.052 * *$

$(-2.02)$

0.014

$(-2.20)$
$3.183^{* *}$
$(-0.60)$

\section{$-0.008$}

$(-0.09)$

0.028

(0.58)

$-0.003^{* *}$

0.107

(0.50)

0.469

(0.78)

$-1.211^{* * *}$

$(-2.63)$

$0.834^{* * * *}$

(2.78)

$-0.205$

$(-0.52)$

$-0.136$

$(-0.73)$

$-0.092$

$(-0.75)$

2.648

(0.86)

$-4.599$

$(-0.82)$

0.116 *

(1.66)

$0.508^{* * * *}$

(9.40)

$0.007^{* * *}$

(5.15)

0.140

(0.39)

0.118 *

(1.90)

$-0.254^{* * *}$

(continued on next page) 
Table 4 (continued)

\begin{tabular}{|c|c|c|c|c|}
\hline Panel B: Multivariate tests fo & $\begin{array}{l}\text { ect of clawback st } \\
\text { (1) CEO turnover } \\
\text { Coef. }\end{array}$ & $\begin{array}{l}\text { ver and compensat } \\
\text { (2) CEO total pay } \\
\text { Marg. Prob. }\end{array}$ & (3) CEO non-incentive pay & (4) CEO incentive pay \\
\hline & $(1.67)$ & $(-5.52)$ & $(0.55)$ & $(-4.27)$ \\
\hline Constant & $\begin{array}{l}1.824 \\
(1.11)\end{array}$ & $\begin{array}{l}3.558^{* * *} \\
(6.86)\end{array}$ & $\begin{array}{l}3.812^{* * *} \\
(11.75)\end{array}$ & $\begin{array}{l}0.221 \\
(0.20)\end{array}$ \\
\hline Year \& industry fixed effects & yes & yes & yes & \\
\hline Observations & 2,441 & 2,441 & 2,441 & 2,441 \\
\hline Pseudo/Adjusted $R^{2}$ & $15.60 \%$ & $38.81 \%$ & $31.30 \%$ & $29.80 \%$ \\
\hline
\end{tabular}

This table presents tests for adopting strong vs. weak clawbacks on the likelihood of CEO turnover and on CEO pay. Strong adopters are propensitymatched to weak adopters, resulting in 249 matched pairs. Panel A reports univariate two-tailed test statistics for differences in means based on the sample we use for our multivariate analysis. We also report, when applicable, the Rosenbaum $\Gamma$ to quantify the amount of hidden bias necessary to alter the statistical significance $(p=0.10)$ in univariate tests that results from the assumption that two observations with identical propensity scores have an equal probability of receiving treatment. Panel B presents multivariate tests (Logit and OLS regressions). We refer to Table A4 in the Internet Appendix for descriptive statistics of all covariates employed in our regressions. Continuous variables are winsorized at $1 \%$ and $99 \%$ and all variables are described in Appendix A. Standard errors are robust to clustering at the year- and firm-level. Z-/T-values are in parentheses. ***, **, * denote significance at the $1 \%, 5 \%$, and $10 \%$ level.

Columns (2-4) in Panel A of Table 4 present the univariate test statistics. We find that CEO pay increases over time both for strong and weak clawback adopters ( $p$-values $<0.01$ ). While total and incentive pay is significantly higher for strong clawback adopters before clawback adoption, pay is lower in the post-adoption period compared to weak adopters. Consequently, the DiD between strong and weak adopters and between the pre- and post-adoption periods are significantly negative for CEO total pay and CEO incentive pay ( $p$-values $<0.05$ ). The decline corresponds to a decrease of USD $1.20 \mathrm{~m}$ in total pay and a USD $1.30 \mathrm{~m}$ decrease in incentive pay. The DiD is negative but not significant for CEO Non-incentive pay.

We then test for the relationship between clawback strength and compensation in a multivariate setting. We estimate equation (2) using an OLS model, include the same set of covariates as in the propensity-score model, and also control for CEO tenure, Share return, and Underperformance. Columns (2-4) in Panel B of Table 4 present the multivariate results. The coefficients on Strong clawback $\times$ After are significantly negative $(p$-value $<0.05)$ in the regressions on CEO total pay and CEO incentive pay. Evaluated at the means, the $\beta_{3}$ coefficient shows a $17.5 \%(23.9 \%)$ reduction in total (incentive) CEO pay for strong clawback adopters compared to weak clawback adopters, between the pre- and post-adoption periods.

Under the isolated clawback explanation (H3a), we expect an increase in pay to induce the CEO to exert effort due to the increase in expected costs that stem from non-controllable reporting risk. Observing a decrease in incentive pay contradicts the isolated clawback explanation but is in line with the broader reform explanation (H3b). Therefore, our findings suggest that firms adopt strong clawbacks simultaneously with other actions to reduce expected costs associated with both controllable and non-controllable reporting risk.

\subsection{Clawback adopters versus non-clawback adopters}

In a last set of tests, we also separately compare strong (weak) clawback adopters to a matched set of firms that do not adopt clawbacks at all. We therefore match strong (weak) adopters to non-adopters based on the estimated propensity-scores from our ordered logistic regression model, as presented in Table 2. The benchmark group now comprises firms that had a similar propensity for adopting a strong (weak) clawback but did not do so. We assign non-adopters the adoption year of their matched pair. We present further information on differences in propensity-scores between strong (weak) adopters and non-adopters, covariate balances, and descriptive statistics in Table A2 in the Appendix.

Table 5 shows that the firm-level outcomes are concentrated only in the sample of strong adopters. We find significant improvements in reporting quality, fewer CEO turnovers, and less total, and non-incentive pay for strong clawback adopters compared to non-adopters, between the pre- and post-adoption periods (panel A). The statistical significance of our results is similar to our main results, while the magnitude of the effects is smaller for most consequences. However, when we compare weak adopters to non-adopters (panel B), our DiD estimator is insignificant for all outcome variables. This finding indicates the adoption of weak clawbacks for window-dressing purposes.

\section{Robustness tests}

\subsection{Sensitivity to hidden bias}

Propensity-score matching and the inclusion of an extensive set of covariates can reduce-but does not necessarily eliminate-the potential for omitted variable bias in our regressions. To assess the sensitivity of our results to omitted variables bias, we adopt an approach developed by Rosenbaum (2002).

Rosenbaum (2002) addresses the selection bias resulting from a potential correlation between unobserved covariates and clawback strength. This approach quantifies how strongly an unobserved covariate must influence the selection process to either nullify or reverse our results. Rosenbaum (2002) shows that relaxing the assumption that two observations with identical observable covariates have an identical probability of receiving treatment can be used for calculating significance test boundaries. These 
Table 5

Clawback adopters versus non-clawback adopters.

\begin{tabular}{|c|c|c|c|}
\hline & Misstatement & Restatement & CEO turnover \\
\hline Strong clawback & $\begin{array}{l}0.365 \\
(1.64)\end{array}$ & $\begin{array}{l}0.425 \\
(1.02)\end{array}$ & $\begin{array}{l}-0.021 \\
(-0.19)\end{array}$ \\
\hline After & $\begin{array}{l}0.205 \\
(0.63)\end{array}$ & $\begin{array}{l}-0.420 \\
(-1.00)\end{array}$ & $\begin{array}{l}-0.131 \\
(-0.77)\end{array}$ \\
\hline Strong clawback $\times$ After & $\begin{array}{l}-1.217^{* * * *} \\
(-3.89)\end{array}$ & $\begin{array}{l}-1.058^{* *} \\
(-2.51)\end{array}$ & $\begin{array}{l}-0.389^{* * *} \\
(-2.63)\end{array}$ \\
\hline Controls, year and industry fixed effects & yes & yes & yes \\
\hline Observations & 3,324 & 3,324 & 2,595 \\
\hline Pseudo $R^{2}$ & $11.10 \%$ & $11.70 \%$ & $16.70 \%$ \\
\hline & CEO total pay & CEO non-incentive pay & CEO incentive pay \\
\hline Strong clawback & $\begin{array}{l}0.099 \\
(1.46)\end{array}$ & $\begin{array}{l}0.043 \\
(0.93)\end{array}$ & $\begin{array}{l}0.251^{*} \\
(1.85)\end{array}$ \\
\hline After & $\begin{array}{l}0.001 \\
(0.02)\end{array}$ & $\begin{array}{l}0.0678 \\
(1.63)\end{array}$ & $\begin{array}{l}-0.030 \\
(-0.20)\end{array}$ \\
\hline Strong clawback $\times$ After & $\begin{array}{l}-0.105^{*} \\
(-1.89)\end{array}$ & $\begin{array}{l}-0.078^{*} \\
(-1.82)\end{array}$ & $\begin{array}{l}-0.138 \\
(-1.05)\end{array}$ \\
\hline Controls, year and industry fixed effects & yes & yes & yes \\
\hline Observations & 2,600 & 2,600 & 2,600 \\
\hline Adjusted $R^{2}$ & $47.77 \%$ & $34.55 \%$ & $30.85 \%$ \\
\hline
\end{tabular}

Panel B: Multivariate tests for matched pairs of weak clawback adopters and non-adopters

\begin{tabular}{|c|c|c|c|}
\hline & Misstatement & Restatement & CEO turnover \\
\hline \multirow[t]{2}{*}{ Weak clawback } & 0.099 & 0.207 & 0.213 \\
\hline & $(0.47)$ & $(1.02)$ & $(1.01)$ \\
\hline \multirow[t]{2}{*}{ After } & $0.473^{*}$ & 0.199 & 0.217 \\
\hline & $(1.78)$ & $(0.71)$ & $(0.84)$ \\
\hline \multirow[t]{2}{*}{ Weak clawback $\times$ After } & 0.022 & 0.186 & -0.405 \\
\hline & $(0.09)$ & $(0.51)$ & $(-1.41)$ \\
\hline Controls, year and industry fixed effects & yes & yes & yes \\
\hline Observations & 3,228 & 3,228 & 2,504 \\
\hline \multirow[t]{2}{*}{ Pseudo $R^{2}$} & $8.28 \%$ & $6.70 \%$ & $14.70 \%$ \\
\hline & CEO total pay & CEO non-incentive pay & CEO incentive pay \\
\hline \multirow[t]{2}{*}{ Weak clawback } & 0.030 & 0.008 & 0.037 \\
\hline & $(0.36)$ & $(0.13)$ & $(0.26)$ \\
\hline \multirow[t]{2}{*}{ After } & 0.077 & 0.043 & 0.137 \\
\hline & $(0.78)$ & $(0.84)$ & $(0.88)$ \\
\hline \multirow[t]{2}{*}{ Weak clawback $\times$ After } & 0.098 & 0.077 & 0.152 \\
\hline & (1.07) & (1.07) & (1.15) \\
\hline Controls, year and industry fixed effects & yes & yes & yes \\
\hline Observations & 2,522 & 2,522 & 2,522 \\
\hline Adjusted $R^{2}$ & $38.50 \%$ & $29.30 \%$ & $28.40 \%$ \\
\hline
\end{tabular}

Panel A (Panel B) reports results when strong (weak) clawback adopters are propensity-matched to non-adopters using the estimated propensity scores from our ordered logistic regression model as presented in Table 2. Table A2 in the Appendix presents covariate balance and descriptive statistics. Continuous variables are winsorized at $1 \%$ and $99 \%$ and all variables are described in Appendix A. Standard errors are robust to clustering at the year- and firm-level. Z-/T-values are in parentheses. $* * *, * *$, denote significance at the $1 \%, 5 \%$, and $10 \%$ level.

boundaries indicate how strong the hidden bias must be for changing the qualitative inferences from a study. The larger the boundary value $\Gamma$, the more robust our inferences are to a potential hidden bias.

We follow Hoitash et al. (2016) and assess the sensitivity of the difference in outcome variables between strong and weak clawback adopters, based on the bounds of the Hodges-Lehmann (HL) point estimate of the average treatment effect. We do so by obtaining the critical $\Gamma$-value for which the upper and lower bounds for the HL estimate bracket zero, indicating an insignificant treatment effect among strong and weak adopters.

We present the Rosenbaum bound, where applicable, in panel A of Tables 3 and 4. The smallest $\Gamma$-value for the six outcome variables is 1.29 (CEO Incentive pay), and the largest $\Gamma$-value is 2.31 (Restatement). While there is no objective benchmark for determining whether a given $\Gamma$-value is large or small (Armstrong et al., 2010, p. 253), our $\Gamma$-values are in line with or even larger than the reported Rosenbaum bounds in Armstrong et al. (2010) and Hoitash et al. (2016). However, as our results are sensitive to 
Table 6

Clawback strength, compensation, and past restatements.

\begin{tabular}{|c|c|c|c|}
\hline & CEO total pay & CEO non-incentive pay & CEO incentive pay \\
\hline \multirow[t]{2}{*}{ Strong clawback } & -0.013 & -0.106 & 0.121 \\
\hline & $(-0.14)$ & $(-1.55)$ & $(0.95)$ \\
\hline \multirow[t]{2}{*}{ After } & $0.159 *$ & 0.026 & 0.195 \\
\hline & (1.87) & $(0.37)$ & $(1.46)$ \\
\hline \multirow[t]{2}{*}{ Strong clawback $\times$ After } & $-0.268^{* *}$ & -0.059 & $-0.579 * * *$ \\
\hline & $(-2.19)$ & $(-0.31)$ & $(-2.59)$ \\
\hline \multirow[t]{2}{*}{ Past restatement } & -0.003 & 0.000 & 0.008 \\
\hline & $(-0.07)$ & $(0.02)$ & $(0.11)$ \\
\hline \multirow{2}{*}{ Past restatement $\times$ Strong clawback $\times$ After } & -0.244 * & -0.036 & $-0.348^{* *}$ \\
\hline & $(-1.77)$ & $(-0.26)$ & $(-2.00)$ \\
\hline Controls, year \& industry fixed effects & Yes & Yes & Yes \\
\hline Observations & 1,327 & 1,327 & 1,327 \\
\hline Adjusted $R^{2}$ & $40.50 \%$ & $36.30 \%$ & $37.20 \%$ \\
\hline
\end{tabular}

This table reports estimation results of the effect of adopting a strong vs. a weak clawback on the level of CEO total, non-incentive, and incentive pay conditional on filing a restatement. The sample contains only firms that have filed a restatement. Strong adopters are propensity-matched to weak adopters. Continuous variables are winsorized at $1 \%$ and $99 \%$ and all variables are described in Appendix A. Standard errors are robust to clustering at the year- and firm-level. T-values are in parentheses. $* * *, * * *$ denote significance at the $1 \%, 5 \%$, and $10 \%$ level.

unobserved heterogeneity, we acknowledge that one should interpret them with caution. ${ }^{7}$

\subsection{Clawback strength, compensation, and past restatements}

Our Clawback Strength Index captures a concept that is abstract and latent rather than concrete and observable. Therefore, one possible concern is the extent to which we actually measure what we want to measure. The ideal way of validating our index would be to show a higher incidence of recoupment for strong adopters than for weak adopters following a triggering event. Unfortunately, this effort is fraught with sample size challenges because firms are not mandated to publicly disclose their clawback actions. ${ }^{8}$ We therefore focus only on firms that have filed a restatement. We then augment our basic model by adding a new variable, Past restatement $\times$ Strong clawback $\times$ After, in the regressions on CEO total pay, CEO non-incentive pay, and CEO incentive pay. The triple interaction term is equal to one for years in which firms have adopted a strong clawback, and after they have filed a restatement.

Table 6 reports the results. We find a significant reduction in total and incentive pay for strong clawback adopters compared to weak clawback adopters, between the pre- and post-adoption periods. Our results show that firms with strong clawbacks lower pay after restatements. One explanation is that this reduction is due to the strong clawback: Firms report current year pay minus any clawback amount. Another explanation is that the drop is a reduction in pay, because firms that adopt strong clawbacks have tougher boards that are more committed to financial reporting integrity. Nevertheless, we find our results comforting in that executives in firms with strong clawbacks experience a reduction in pay following earnings restatements.

\subsection{Further robustness tests}

We conduct the following robustness tests. First, we use the full sample of clawback adopters without matching strong to weak adopters. While this approach uses a much larger sample, it has the disadvantage that we do not control for a potential self-selection into adopting a strong or weak clawback or no clawback. We present the results in Table A3 in the Appendix. Our findings remain qualitatively similar, while the coefficients on Strong clawback $\times$ After are generally smaller in magnitude.

Second, we study the sensitivity of our results to alternative constructions of our index. We assume that the overall clawback is stronger, when (a) boards have less discretion as to whether to invoke the clawback, and when (b) the clawback is not triggered by misconduct. Therefore, we assign a greater weight to the misconduct hurdle (Table A4, Panel A), use a multiplicative version of our Clawback Strength Index (Table A4, Panel B), and exclude non-financial triggers from the Trigger sub-index (Table A4, Panel C). We also consider an alternative index and exclude the Employee Coverage sub-index from the overall Clawback Strength Index. The assumption is that some of the elements of the Employee Coverage sub-index do not strengthen the CEO's clawback but reduce the noncontrollable reporting risk (Table A4, Panel D). Finally, we reconstruct the Clawback Strength Index by classifying strong and weak adopters through using alternative cut-off points at the yearly 75 th/25th percentile of the index distribution, rather than the yearly median (Table A4, Panel E). In all of these robustness tests, our inferences remain qualitatively similar.

\footnotetext{
${ }^{7}$ We also adopt an approach developed by Hosman et al. (2010) to assess a potential omitted variables bias. All details and results are presented in Internet Appendix C. We report that, in the majority of cases, our coefficient estimates are robust to various scenarios of omitted covariates.

${ }^{8}$ Internet Appendix A summarizes all SEC enforced clawback cases and illustrates the out-of-pocket costs for executives due to clawback enforcement.
} 


\section{Conclusion}

In this study, we draw on firms' freedom to draft voluntarily adopted clawback provisions. To explore the cross-sectional variation in clawbacks, we study the design of 4,464 clawback provisions and propose a Clawback Strength Index. Our index confirms that some firms adopt strong and substantive provisions, whereas other firms adopt weak ones.

We show that, following clawback adoption, strong clawback adopters in comparison with weak clawback adopters experience significant improvements in financial reporting quality, a decrease in the likelihood of CEO turnover, and a decrease in both total and incentive-based CEO pay. Moreover, we find similar results when comparing strong adopters to a sample of non-adopters, whereas we find no beneficial changes when comparing weak adopters to a sample of non-adopters.

Our findings for financial reporting quality and CEO turnover reveal that if clawbacks have causal effects, then these effects stem from clawback strength, not from clawback adoption per se. Furthermore, the improvements in reporting quality and the fewer CEO turnovers can also reflect the effect of a broader reform in which firms adopt strong clawbacks, along with other measures, to reduce overall reporting risk stemming from factors outside the CEO's immediate control. This reduction removes the necessity of increasing compensation after clawback adoption and explains our findings on CEO pay.

Our study provides first evidence of the differential economic consequences across voluntary clawback adopters. Viewed collectively, our results confirm that not all clawbacks are the same: Some clawbacks lead to significant economic benefits, while others do not. We therefore contribute to a richer understanding of the economic consequences of clawback adoption. An important implication of our study is that one may need to reinterpret the results of prior clawback studies, which find beneficial effects of clawback adoption and attribute these effects causally to merely adopting a clawback. This interpretation overlooks the variation in clawback design and the notion that governance mechanisms interact in potentially important ways (Denis, 2001, 2012), thereby omitting the beneficial impact of concomitant governance changes that are embedded in a broader reform. From this perspective, the effect sizes attributed by prior literature to clawback adoption may be upward biased.

Our study also contributes to the literature on the voluntary initiation of corporate governance mechanisms in general. While researchers are able to observe the adoption of such mechanisms, they are generally unable to observe the underlying motives for the adoption. Our approach of studying the design of governance mechanisms and of differentiating between weak and strong designs can help future researchers make useful inferences about firms' motives for the adoption of governance tools. More specifically, the existence of two different types of clawbacks suggests the initiation of such provisions for either window-dressing purposes or substantial reasons. Future research will likely find it fruitful to pay more attention to the design of governance tools when making inferences about firms' motives for their adoption.

Our study is subject to the following limitations. First, we cannot rule out the possibility that boards adopt strong clawbacks merely to signal their greater commitment to improving reporting quality. Given that SOX already introduced a clawback provision long before our sample firms have chosen to adopt their own provisions supports this signaling argument. Thus, clawbacks may not have any effects and firms only adopt them to signal the boards' commitment to better reporting quality (Denis, 2012). However, whereas many of the firms' actions to reduce reporting risk and the board's level of oversight are not observable (Laux and Laux, 2009), the adoption of a strong clawback is. Observing the strength of a clawback is therefore meaningful, because it reveals important information that is otherwise not visible to shareholders.

Second, and related to the difficulty of observing firms' actions towards improving their reporting, we are not able to provide conclusive evidence that firms adopt strong clawbacks as part of a broader reform. Because most of the components of the reform can vary across time and firms, not only capturing them in the cross-section but also, and consequently, assessing the specific contribution of the clawback to the overall effect is difficult. Nonetheless, by analyzing the effect of clawback strength on CEO pay, we can distinguish between the isolated clawback and the broader reform explanation. The decrease in CEO pay, together with the uniformly strong improvements in reporting quality following the adoption of a strong clawback, suggests that differences in clawback design reflect differences in firms' motivation for reducing reporting risk. Thus our overall set of results favors the broader reform explanation: Firms that care a great deal about their reporting are likely to adopt strong clawbacks as part of a broader reform.

Third, our model assumes that non-controllable reporting risk is not affected by clawback adoption. However, CEOs exposed to a strong clawback may themselves initiate governance mechanisms to reduce non-controllable reporting risk. Under this scenario, the broader reform package is adopted in response to the clawback, thereby strengthening the importance of adopting a clawback in isolation. However, if CEOs exert more effort to further decrease non-controllable reporting risk, one would expect an increase in CEO pay. Our results are the opposite, lending support to the broader reform explanation.

These limitations notwithstanding, our findings also have implications for shareholders and regulators. Given that the mere adoption of clawbacks does not warrant better reporting quality, one must be cautious about assuming that mandating clawback provisions under Section 954 of the Dodd-Frank Act will be beneficial. Moreover, even if Section 954 will eventually require the design of strong clawbacks, it is not clear that firms that have chosen to adopt a weak clawback or no clawback at all will be as diligent in enforcing them as firms that have chosen to adopt a strong clawback. It also remains unclear whether the CEOs of non- or weak adopters will improve reporting quality as effectively as the CEOs of strong adopters. Future research could reexamine the effectiveness of clawback provisions by comparing the economic consequences of voluntary and mandatory adoption. 
Table A1

Descriptive statistics.

Panel A: Descriptive statistics for analyses of misstatement, restatement, CEO turnover, and CEO pay

\begin{tabular}{|c|c|c|c|c|c|c|}
\hline & \multicolumn{3}{|c|}{ (1) Misstatement and restatement analysis } & \multicolumn{3}{|c|}{ (2) CEO turnover and CEO pay analysis } \\
\hline & Mean & Median & SD & Mean & Median & SD \\
\hline Audit committee size & 4.932 & 5.000 & 2.837 & 5.130 & 5.000 & 2.868 \\
\hline Board meetings & 8.071 & 7.000 & 3.391 & 7.912 & 7.000 & 3.229 \\
\hline Cash return & 0.146 & 0.139 & 0.111 & 0.158 & 0.144 & 0.097 \\
\hline CEO age & & & & 55.957 & 56.000 & 6.740 \\
\hline CEO chair & 0.543 & 1.000 & 0.498 & 0.576 & 1.000 & 0.494 \\
\hline CEO tenure & & & & 7.555 & 5.808 & 6.558 \\
\hline Chg. in acc. receivables & 0.008 & 0.005 & 0.036 & 0.008 & 0.005 & 0.035 \\
\hline Discretionary accruals & 0.063 & 0.030 & 0.101 & 0.061 & 0.029 & 0.100 \\
\hline Independent directors & 0.753 & 0.765 & 0.086 & 0.755 & 0.765 & 0.084 \\
\hline Insider ownership & 0.080 & 0.036 & 0.129 & 0.071 & 0.034 & 0.116 \\
\hline Institutional ownership & 0.827 & 0.843 & 0.169 & 0.840 & 0.849 & 0.153 \\
\hline Leverage & 0.222 & 0.208 & 0.178 & 0.211 & 0.202 & 0.162 \\
\hline Loss & 0.166 & 0.000 & 0.372 & 0.132 & 0.000 & 0.338 \\
\hline Past restatement & 0.067 & 0.000 & 0.250 & 0.061 & 0.000 & 0.239 \\
\hline $\mathrm{R} \& \mathrm{D}$ & 0.081 & 0.002 & 0.530 & 0.047 & 0.003 & 0.146 \\
\hline Return on assets & 0.040 & 0.052 & 0.114 & 0.051 & 0.056 & 0.100 \\
\hline Return volatility & 0.027 & 0.024 & 0.013 & 0.025 & 0.023 & 0.012 \\
\hline Sales growth & 0.093 & 0.070 & 0.274 & 0.081 & 0.067 & 0.226 \\
\hline Size & 7.881 & 7.676 & 1.487 & 8.035 & 7.839 & 1.468 \\
\hline Share return & & & & 0.048 & -0.192 & 8.111 \\
\hline Soft assets & 0.569 & 0.604 & 0.227 & 0.576 & 0.611 & 0.220 \\
\hline Tobin's Q & 1.719 & 1.392 & 1.089 & 1.721 & 1.411 & 1.060 \\
\hline Underperformance & & & & 0.635 & 1.000 & 0.481 \\
\hline Number of observations & 2,935 & & & 2,441 & & \\
\hline
\end{tabular}

Panel B: Descriptive statistics for analyses of (unexplained) audit fees, meet/beat and ERC

\begin{tabular}{|c|c|c|c|c|c|c|}
\hline & \multicolumn{3}{|c|}{ (1) (Unexplained) audit fees } & \multicolumn{3}{|c|}{ (2) Meet/beat and ERC } \\
\hline & Mean & Median & SD & Mean & Median & SD \\
\hline Altman Z-score & & & & 2.478 & 1.921 & 3.786 \\
\hline Audit committee size & 4.910 & 5.000 & 2.618 & 5.245 & 5.000 & 3.132 \\
\hline BIG 4 & 0.950 & 1.000 & 0.218 & & & \\
\hline Board meetings & 7.917 & 7.000 & 3.290 & 8.142 & 7.000 & 3.356 \\
\hline Book-to-market & & & & 0.563 & 0.503 & 0.444 \\
\hline Capital intensity & & & & 5.371 & 2.193 & 20.387 \\
\hline Cash return & 0.149 & 0.140 & 0.111 & 0.027 & 0.026 & 0.046 \\
\hline CEO chair & & & & 0.551 & 1.000 & 0.498 \\
\hline Current ratio & 2.242 & 1.834 & 1.521 & & & \\
\hline Debt issuance & 0.337 & 0.000 & 0.473 & & & \\
\hline Discretionary accruals & 0.061 & 0.031 & 0.096 & 0.061 & 0.028 & 0.104 \\
\hline Downward revision & & & & 0.315 & 0.000 & 0.465 \\
\hline Earnings growth & & & & 0.539 & 1.000 & 0.499 \\
\hline Earnings surprise & & & & 0.000 & 0.001 & 0.041 \\
\hline Extraordinary items & 0.024 & 0.000 & 0.152 & & & \\
\hline Foreign sales & 0.212 & 0.074 & 2.656 & & & \\
\hline Fourth fiscal quarter & & & & 0.267 & 0.000 & 0.443 \\
\hline Independent directors & 0.764 & 0.773 & 0.091 & 0.764 & 0.778 & 0.089 \\
\hline Insider ownership & 0.082 & 0.037 & 0.130 & 0.075 & 0.030 & 0.134 \\
\hline Institutional ownership & 0.820 & 0.837 & 0.171 & 0.801 & 0.820 & 0.164 \\
\hline Inventory & 4.774 & 5.153 & 2.217 & & & \\
\hline Leverage & 0.219 & 0.205 & 0.174 & 0.249 & 0.237 & 0.188 \\
\hline Loss & 0.156 & 0.000 & 0.363 & 0.168 & 0.000 & 0.374 \\
\hline Nonlinear median & & & & 0.000 & 0.000 & 0.075 \\
\hline Number of estimates & & & & 12.224 & 10.000 & 7.983 \\
\hline Past meet-beat & & & & 0.642 & 1.000 & 0.479 \\
\hline Past restatement & 0.064 & 0.000 & 0.246 & 0.063 & 0.000 & 0.242 \\
\hline Receivables & 5.502 & 5.590 & 1.688 & & & \\
\hline $\mathrm{R} \& \mathrm{D}$ & 0.077 & 0.003 & 0.496 & & & \\
\hline
\end{tabular}


Table A1 (continued)

\begin{tabular}{|c|c|c|c|c|c|c|}
\hline Return on assets & 0.043 & 0.053 & 0.110 & 0.011 & 0.013 & 0.058 \\
\hline Return volatility & 0.026 & 0.023 & 0.012 & 0.041 & 0.031 & 0.035 \\
\hline Sales growth & 0.132 & 0.081 & 0.754 & 0.032 & 0.016 & 0.378 \\
\hline SEO & 0.050 & 0.000 & 0.218 & & & \\
\hline Size & 7.897 & 7.695 & 1.471 & 8.141 & 8.090 & 1.539 \\
\hline Shares & & & & 4.734 & 4.561 & 1.254 \\
\hline Soft assets & & & & 0.281 & 0.320 & 0.387 \\
\hline Tobin's Q & 1.767 & 1.415 & 1.133 & & & \\
\hline Write-off & & & & 0.484 & 0.000 & 0.500 \\
\hline Number of observations & 3,367 & & & 6,479 & & \\
\hline
\end{tabular}

Column (1) of Panel A presents descriptive statistics of the matched sample of strong clawback adopters vs. weak clawback adopters for the analyses of misstatements and restatements. Of the 2,935 observations, $1,474(1,461)$ belong to strong (weak) clawback adopters, and $1,677(1,258)$ to before (after) clawback adoption. Column (2) of Panel A presents descriptive statistics for the analyses of CEO turnover and CEO pay. Of the 2,441 observations, $1,217(1,224)$ belong to strong (weak) clawback adopters, and 1,355 $(1,086)$ to before (after) clawback adoption.

Column (1) of Panel B presents descriptive statistics of the matched sample of strong clawback adopters vs. weak clawback adopters for the analyses of (unexplained) audit fees. Of the 3,367 observations, $1,711(1,656)$ belong to strong (weak) clawback adopters, and 2,181 $(1,186)$ to before (after) clawback adoption. Column (2) of Panel B presents descriptive statistics for the analyses of meet/beat behavior and the ERC analysis. Of the 6,479 observations, 3,328 $(3,151)$ belong to strong (weak) clawback adopters, and 3,561 $(2,918)$ to before (after) clawback adoption. Continuous variables are winsorized at $1 \%$ and $99 \%$, and all variables are described in Appendix A.

Table A2

Matching strong (weak) clawback adopters to non-adopters.

\begin{tabular}{|c|c|c|c|c|c|c|}
\hline Panel A: Differe & $\begin{array}{l}\text { sity-scores for } \mathrm{m} \\
\text { Matched pairs }\end{array}$ & Mean & SD & Min. & Median & Max \\
\hline Strong vs. Non & 299 & 0.004 & 0.007 & 0.000 & 0.001 & 0.029 \\
\hline Weak vs. Non & 287 & 0.004 & 0.007 & 0.000 & 0.001 & 0.029 \\
\hline
\end{tabular}

Panel B: Covariate balance between the matched pairs of 299 strong and 299 non-clawback adopters

\begin{tabular}{|c|c|c|c|c|c|c|c|}
\hline & Mean strong & Mean non & Median strong & Median non & $t$-test diff. p-value & KS boot-strap diff. p-value & Norm. diff. \\
\hline Audit comm. size & 5.080 & 5.044 & 5.000 & 5.000 & 0.818 & 0.651 & 0.019 \\
\hline Board meetings & 8.044 & 8.171 & 7.000 & 7.000 & 0.660 & 0.999 & -0.036 \\
\hline Cash return & 0.132 & 0.134 & 0.134 & 0.137 & 0.848 & 0.515 & -0.016 \\
\hline CEO chair & 0.495 & 0.508 & 0.000 & 1.000 & 0.744 & 1.000 & -0.027 \\
\hline Chg. in acc. rec. & 0.003 & 0.004 & 0.003 & 0.004 & 0.585 & 0.846 & -0.045 \\
\hline Discretionary acc. & 0.070 & 0.073 & 0.036 & 0.038 & 0.748 & 0.515 & -0.026 \\
\hline Independent dir. & 0.742 & 0.746 & 0.750 & 0.750 & 0.569 & 0.582 & -0.047 \\
\hline Insider ownership & 0.111 & 0.108 & 0.048 & 0.053 & 0.781 & 0.719 & 0.023 \\
\hline Institutional own. & 0.810 & 0.809 & 0.832 & 0.863 & 0.968 & 0.145 & 0.003 \\
\hline Leverage & 0.231 & 0.224 & 0.212 & 0.208 & 0.663 & 0.393 & 0.036 \\
\hline Loss & 0.181 & 0.204 & 0.000 & 0.000 & 0.469 & 1.000 & -0.059 \\
\hline Past restatement & 0.054 & 0.070 & 0.000 & 0.000 & 0.397 & 1.000 & -0.069 \\
\hline $\mathrm{R} \& \mathrm{D}$ & 0.178 & 0.115 & 0.004 & 0.000 & 0.412 & 0.651 & 0.067 \\
\hline Return on assets & 0.026 & 0.026 & 0.044 & 0.044 & 0.991 & 0.785 & -0.001 \\
\hline Return volatility & 0.030 & 0.030 & 0.027 & 0.027 & 0.973 & 0.846 & 0.003 \\
\hline Sales growth & 0.073 & 0.098 & 0.066 & 0.062 & 0.378 & 0.582 & -0.072 \\
\hline Size & 7.266 & 7.262 & 7.287 & 7.174 & 0.970 & 0.582 & 0.003 \\
\hline Soft assets & 0.558 & 0.562 & 0.588 & 0.599 & 0.845 & 0.970 & -0.016 \\
\hline Tobin's Q & 1.770 & 1.740 & 1.397 & 1.412 & 0.757 & 0.719 & 0.025 \\
\hline
\end{tabular}

Panel C: Covariate balance between the matched pairs of 287 weak and 287 non-clawback adopters

\begin{tabular}{|c|c|c|c|c|c|c|c|}
\hline & Mean strong & Mean non & Median strong & Median non & $t$-test diff. p-value & KS boot-strap diff. p-value & Norm. diff. \\
\hline Audit comm. size & 4.781 & 4.896 & 4.000 & 5.000 & 0.453 & 0.828 & -0.063 \\
\hline Board meetings & 8.101 & 8.077 & 7.000 & 7.000 & 0.935 & 0.489 & 0.007 \\
\hline Cash return & 0.140 & 0.138 & 0.134 & 0.137 & 0.904 & 0.625 & 0.010 \\
\hline CEO chair & 0.512 & 0.495 & 1.000 & 0.000 & 0.677 & 1.000 & 0.035 \\
\hline
\end{tabular}


Table A2 (continued)

\begin{tabular}{|c|c|c|c|c|c|c|c|}
\hline Chg. in acc. rec. & 0.010 & 0.008 & 0.007 & 0.007 & 0.649 & 0.764 & 0.038 \\
\hline Discretionary acc. & 0.067 & 0.081 & 0.037 & 0.042 & 0.147 & 0.625 & -0.121 \\
\hline Independent dir. & 0.738 & 0.737 & 0.750 & 0.750 & 0.896 & 0.556 & 0.011 \\
\hline Insider ownership & 0.122 & 0.109 & 0.054 & 0.053 & 0.288 & 0.930 & 0.089 \\
\hline Institutional own. & 0.805 & 0.802 & 0.836 & 0.844 & 0.866 & 0.695 & 0.014 \\
\hline Leverage & 0.212 & 0.218 & 0.186 & 0.174 & 0.738 & 0.426 & -0.028 \\
\hline Loss & 0.220 & 0.202 & 0.000 & 0.000 & 0.610 & 1.000 & 0.043 \\
\hline Past restatement & 0.084 & 0.066 & 0.000 & 0.000 & 0.429 & 1.000 & 0.066 \\
\hline $\mathrm{R} \& \mathrm{D}$ & 0.114 & 0.111 & 0.000 & 0.006 & 0.959 & 0.130 & 0.004 \\
\hline Return on assets & 0.029 & 0.020 & 0.044 & 0.045 & 0.477 & 0.625 & 0.059 \\
\hline Return volatility & 0.029 & 0.029 & 0.027 & 0.027 & 0.912 & 0.884 & -0.009 \\
\hline Sales growth & 0.123 & 0.147 & 0.087 & 0.085 & 0.465 & 0.426 & -0.061 \\
\hline Size & 7.170 & 7.116 & 7.122 & 7.164 & 0.638 & 0.984 & 0.039 \\
\hline Soft assets & 0.544 & 0.564 & 0.570 & 0.584 & 0.314 & 0.226 & -0.084 \\
\hline Tobin's Q & 1.832 & 1.913 & 1.432 & 1.423 & 0.480 & 0.695 & -0.059 \\
\hline
\end{tabular}

Panel D: Descriptive statistics for analyses of strong vs. non-clawback

(1) Misstatement and restatement analysis

\begin{tabular}{|c|c|c|c|c|c|c|}
\hline & Mean & Median & SD & Mean & Median & SD \\
\hline Audit committee size & 4.801 & 4.000 & 2.735 & 5.032 & 5.000 & 2.814 \\
\hline Board meetings & 7.874 & 7.000 & 3.383 & 7.789 & 7.000 & 3.325 \\
\hline Cash return & 0.146 & 0.139 & 0.116 & 0.160 & 0.147 & 0.095 \\
\hline CEO age & & & & 55.910 & 56.000 & 7.060 \\
\hline CEO chair & 0.511 & 1.000 & 0.500 & 0.532 & 1.000 & 0.499 \\
\hline CEO tenure & & & & 7.825 & 5.849 & 7.050 \\
\hline Chg. in acc. receivables & 0.008 & 0.005 & 0.036 & 0.008 & 0.005 & 0.033 \\
\hline Discretionary accruals & 0.059 & 0.032 & 0.092 & 0.055 & 0.032 & 0.084 \\
\hline Independent directors & 0.747 & 0.762 & 0.085 & 0.750 & 0.765 & 0.085 \\
\hline Insider ownership & 0.091 & 0.042 & 0.141 & 0.081 & 0.039 & 0.132 \\
\hline Institutional ownership & 0.825 & 0.856 & 0.193 & 0.846 & 0.866 & 0.175 \\
\hline Leverage & 0.217 & 0.200 & 0.182 & 0.206 & 0.190 & 0.166 \\
\hline Loss & 0.182 & 0.000 & 0.386 & 0.139 & 0.000 & 0.346 \\
\hline Past restatement & 0.061 & 0.000 & 0.240 & 0.058 & 0.000 & 0.233 \\
\hline $\mathrm{R} \& \mathrm{D}$ & 0.094 & 0.001 & 0.661 & 0.041 & 0.002 & 0.078 \\
\hline Return on assets & 0.037 & 0.049 & 0.118 & 0.052 & 0.055 & 0.094 \\
\hline Return volatility & 0.027 & 0.024 & 0.014 & 0.026 & 0.023 & 0.013 \\
\hline Sales growth & 0.089 & 0.067 & 0.280 & 0.072 & 0.065 & 0.192 \\
\hline Size & 7.461 & 7.395 & 1.273 & 7.623 & 7.540 & 1.220 \\
\hline Share return & & & & -0.112 & -0.201 & 1.944 \\
\hline Soft assets & 0.577 & 0.616 & 0.226 & 0.590 & 0.623 & 0.212 \\
\hline Tobin's Q & 1.742 & 1.401 & 1.100 & 1.748 & 1.430 & 1.055 \\
\hline Underperformance & & & & 0.634 & 1.000 & 0.482 \\
\hline Number of observations & 3,324 & & & 2,600 & & \\
\hline
\end{tabular}

Panel E: Descriptive statistics for analyses of weak vs. non-clawback

(1) Misstatement and restatement analysis

(2) CEO turnover and CEO pay analysis

\begin{tabular}{|c|c|c|c|c|c|c|}
\hline & Mean & Median & SD & Mean & Median & SD \\
\hline Audit committee size & 4.588 & 4.000 & 2.584 & 4.795 & 5.000 & 2.658 \\
\hline Board meetings & 8.063 & 7.000 & 3.535 & 7.844 & 7.000 & 3.310 \\
\hline Cash return & 0.143 & 0.136 & 0.121 & 0.158 & 0.145 & 0.104 \\
\hline CEO age & & & & 56.059 & 56.000 & 7.637 \\
\hline CEO chair & 0.515 & 1.000 & 0.500 & 0.530 & 1.000 & 0.499 \\
\hline CEO tenure & & & & 8.442 & 6.425 & 7.142 \\
\hline Chg. in acc. receivables & 0.010 & 0.005 & 0.038 & 0.010 & 0.006 & 0.037 \\
\hline Discretionary accruals & 0.063 & 0.033 & 0.094 & 0.059 & 0.031 & 0.092 \\
\hline Independent directors & 0.734 & 0.750 & 0.097 & 0.744 & 0.750 & 0.092 \\
\hline Insider ownership & 0.112 & 0.051 & 0.154 & 0.090 & 0.044 & 0.126 \\
\hline Institutional ownership & 0.808 & 0.843 & 0.199 & 0.839 & 0.865 & 0.176 \\
\hline Leverage & 0.215 & 0.189 & 0.202 & 0.201 & 0.185 & 0.178 \\
\hline Loss & 0.191 & 0.000 & 0.393 & 0.142 & 0.000 & 0.350 \\
\hline Past restatement & 0.073 & 0.000 & 0.261 & 0.072 & 0.000 & 0.258 \\
\hline $\mathrm{R} \& \mathrm{D}$ & 0.094 & 0.000 & 0.619 & 0.062 & 0.000 & 0.393 \\
\hline Return on assets & 0.035 & 0.047 & 0.117 & 0.048 & 0.054 & 0.101 \\
\hline Return volatility & 0.028 & 0.025 & 0.013 & 0.026 & 0.024 & 0.012 \\
\hline Sales growth & 0.109 & 0.075 & 0.307 & 0.096 & 0.074 & 0.251 \\
\hline
\end{tabular}

(continued on next page) 
Table A2 (continued)

\begin{tabular}{|c|c|c|c|c|c|c|}
\hline Size & 7.342 & 7.261 & 1.413 & 7.541 & 7.483 & 1.385 \\
\hline Share return & & & & -0.060 & -0.202 & 2.283 \\
\hline Soft assets & 0.562 & 0.585 & 0.228 & 0.569 & 0.595 & 0.222 \\
\hline Tobin's Q & 1.792 & 1.410 & 1.227 & 1.816 & 1.459 & 1.173 \\
\hline Underperformance & & & & 0.639 & 1.000 & 0.480 \\
\hline Number of observations & 3,228 & & & 2,522 & & \\
\hline
\end{tabular}

Panel A presents statistics on the differences in propensity-scores between matched pairs of strong (weak) and non-clawback adopters. Panel B (Panel C) presents the test statistics of covariate distributions for strong (weak) clawback adopters and non-clawback adopters. We show the pvalues for a parametric $t$-test of the difference in means and a non-parametric Kolmogorov-Smirnov (KS) test of the difference between two distributions. Following Sekhon (2006), we bootstrap the KS-test with 2,000 bootstrap samples. We also report normalized differences to assess the economic significance of reported differences. Normalized differences is the difference in means for strong and weak adopter groups divided by the square root of the average of the group variances. A normalized difference of 0.25 or less indicates an acceptable balance (Imbens and Wooldridge, 2009). Column (1) of Panel D presents descriptive statistics of the matched sample of strong clawback adopters vs. non-adopters for the analyses of misstatements and restatements. Of the 3,324 observations, $1,759(1,565)$ belong to strong (non) clawback adopters, and 1,919 $(1,405)$ to before (after) clawback adoption. Column (2) of Panel D presents descriptive statistics for the analyses of CEO turnover and CEO pay. Of the 2,600 observations, 1,402 (1,198) belong to strong (non) clawback adopters, and 1,446 (1,154) to before (after) clawback adoption. Column (1) of Panel E presents descriptive statistics of the matched sample weak clawback adopters vs. non-adopters for the analyses of misstatements and restatements. Of the 3,228 observations, 1,688 (1,540) belong to weak (non) clawback adopters, and 1,835 $(1,393)$ to before (after) clawback adoption. Column (2) of Panel E presents descriptive statistics for the analyses of CEO turnover and CEO pay. Of the 2,522 observations, 1,325 (1,197) belong to weak (non) clawback adopters, and 1,382 $(1,140)$ to before (after) clawback adoption. Continuous variables are winsorized at $1 \%$ and $99 \%$, and all variables are described in Appendix A. ***, **, and * denote significance at the $1 \%, 5 \%$, and $10 \%$ level, respectively.

Table A3

No matching of strong and weak clawback adopters.

\begin{tabular}{|c|c|c|c|}
\hline & Misstatement & Restatement & Turnover \\
\hline Strong clawback & $\begin{array}{l}-0.085 \\
(-0.42)\end{array}$ & $\begin{array}{l}0.075 \\
(0.34)\end{array}$ & $\begin{array}{l}0.118 \\
(0.72)\end{array}$ \\
\hline After & $\begin{array}{l}0.204 \\
(1.06)\end{array}$ & $\begin{array}{l}0.185 \\
(0.66)\end{array}$ & $\begin{array}{l}-0.056 \\
(-0.29)\end{array}$ \\
\hline Strong clawback $\times$ After & $\begin{array}{l}-0.861^{* * *} \\
(-3.99)\end{array}$ & $\begin{array}{l}-1.072^{* * *} \\
(-2.93)\end{array}$ & $\begin{array}{l}-0.474^{* * *} \\
(-2.84)\end{array}$ \\
\hline Controls, year and industry fixed effects & yes & yes & yes \\
\hline Observations & 4,408 & 4,408 & 3,455 \\
\hline \multirow[t]{2}{*}{ Pseudo $R^{2}$} & $7.44 \%$ & $7.05 \%$ & $15.70 \%$ \\
\hline & CEO total pay & CEO non-incentive pay & CEO incentive pay \\
\hline Strong clawback & $\begin{array}{l}0.089 \\
(1.50)\end{array}$ & $\begin{array}{l}0.015 \\
(0.40)\end{array}$ & $\begin{array}{l}0.190^{*} \\
(1.76)\end{array}$ \\
\hline After & $\begin{array}{l}0.105 \\
(1.34)\end{array}$ & $\begin{array}{l}0.054 \\
(0.96)\end{array}$ & $\begin{array}{l}0.167^{*} \\
(1.89)\end{array}$ \\
\hline Strong clawback $\times$ After & $\begin{array}{l}-0.131^{* *} \\
(-2.48)\end{array}$ & $\begin{array}{l}-0.026 \\
(-0.65)\end{array}$ & $\begin{array}{l}-0.215^{* *} \\
(-2.37)\end{array}$ \\
\hline Controls, year and industry fixed effects & yes & yes & yes \\
\hline Observations & 3,458 & 3,458 & 3,458 \\
\hline Adjusted $R^{2}$ & $44.90 \%$ & $32.60 \%$ & $32.70 \%$ \\
\hline
\end{tabular}

This table presents results if strong clawback adopters are not propensity-matched to weak clawback adopters. Continuous variables are winsorized at $1 \%$ and $99 \%$, and all variables are described in Appendix A. Standard errors are robust to clustering at the year and firm levels. Z/T-values are in parentheses. ${ }^{* * *}, * *$, and $*$ denote significance at the $1 \%, 5 \%$, and $10 \%$ level, respectively. 
Table A4

Robustness tests on index construction.

\begin{tabular}{|c|c|c|c|}
\hline Panel A: Trigger subindex is set to zero $\mathrm{i}$ & Misstatement & Restatement & Turnover \\
\hline \multirow[t]{2}{*}{ Strong clawback } & 0.112 & 0.096 & 0.137 \\
\hline & $(0.55)$ & $(0.59)$ & (1.11) \\
\hline \multirow[t]{2}{*}{ After } & 0.333 & 0.377 & -0.240 \\
\hline & $(1.64)$ & (1.54) & $(-0.88)$ \\
\hline \multirow[t]{2}{*}{ Strong clawback $\times$ After } & $-1.289 * * *$ & $-1.597 * *$ & $-0.410^{* * *}$ \\
\hline & $(-3.38)$ & $(-2.24)$ & $(-2.85)$ \\
\hline Controls, year and industry fixed effects & yes & yes & yes \\
\hline Observations & 2,914 & 2,914 & 2,354 \\
\hline \multirow[t]{2}{*}{ Pseudo $R^{2}$} & $12.30 \%$ & $11.60 \%$ & $14.00 \%$ \\
\hline & CEO total pay & CEO non-incentive pay & CEO incentive pay \\
\hline \multirow[t]{2}{*}{ Strong clawback } & 0.032 & -0.036 & 0.125 \\
\hline & $(0.59)$ & $(-0.93)$ & $(1.42)$ \\
\hline \multirow[t]{2}{*}{ After } & -0.000 & -0.035 & -0.032 \\
\hline & $(-0.01)$ & $(-0.96)$ & $(-0.39)$ \\
\hline \multirow[t]{2}{*}{ Strong clawback $\times$ After } & $-0.081 * *$ & 0.035 & $-0.099 * *$ \\
\hline & $(-1.98)$ & (1.00) & $(-1.99)$ \\
\hline Controls, year and industry fixed effects & yes & yes & yes \\
\hline Observations & 2,354 & 2,354 & 2,354 \\
\hline Adjusted $R^{2}$ & $52.10 \%$ & $36.00 \%$ & $34.00 \%$ \\
\hline
\end{tabular}

Panel B: Multiply Trigger subindex with the sum of other indices

\begin{tabular}{|c|c|c|c|}
\hline & Misstatement & Restatement & Turnover \\
\hline Strong clawback & $\begin{array}{l}-0.059 \\
(-0.27)\end{array}$ & $\begin{array}{l}-0.043 \\
(-0.24)\end{array}$ & $\begin{array}{l}0.298^{* *} \\
(2.13)\end{array}$ \\
\hline After & $\begin{array}{l}0.420^{* *} \\
(2.29)\end{array}$ & $\begin{array}{l}0.408 \\
(1.50)\end{array}$ & $\begin{array}{l}-0.030 \\
(-0.17)\end{array}$ \\
\hline Strong clawback $\times$ After & $\begin{array}{l}-0.980^{* * *} \\
(-4.03)\end{array}$ & $\begin{array}{l}-1.047^{* * *} \\
(-2.76)\end{array}$ & $\begin{array}{l}-0.405^{* *} \\
(-1.96)\end{array}$ \\
\hline Controls, year and industry fixed effects & yes & yes & yes \\
\hline Observations & 3,018 & 3,018 & 2,477 \\
\hline Pseudo $R^{2}$ & $10.20 \%$ & $9.94 \%$ & $16.50 \%$ \\
\hline & CEO total pay & CEO non-incentive pay & CEO incentive pay \\
\hline Strong clawback & $\begin{array}{l}0.075 \\
(0.80)\end{array}$ & $\begin{array}{l}0.016 \\
(0.24)\end{array}$ & $\begin{array}{l}0.228 \\
(1.62)\end{array}$ \\
\hline After & $\begin{array}{l}0.116 \\
(0.93)\end{array}$ & $\begin{array}{l}0.039 \\
(0.48)\end{array}$ & $\begin{array}{l}0.151 \\
(1.05)\end{array}$ \\
\hline Strong clawback $\times$ After & $\begin{array}{l}-0.165^{*} \\
(-1.75)\end{array}$ & $\begin{array}{c}-0.045 \\
(-0.67)\end{array}$ & $\begin{array}{l}-0.261^{*} \\
(-1.91)\end{array}$ \\
\hline Controls, year and industry fixed effects & yes & yes & yes \\
\hline Observations & 2,477 & 2,477 & 2,477 \\
\hline Adjusted $R^{2}$ & $41.40 \%$ & $31.70 \%$ & $34.50 \%$ \\
\hline
\end{tabular}

Panel C: No non-financial triggers

\begin{tabular}{|c|c|c|c|}
\hline & Misstatement & Restatement & Turnover \\
\hline Strong clawback & $\begin{array}{l}-0.028 \\
(-0.14)\end{array}$ & $\begin{array}{l}0.119 \\
(0.81)\end{array}$ & $\begin{array}{l}0.133 \\
(0.52)\end{array}$ \\
\hline After & $\begin{array}{l}0.332 \\
(1.63)\end{array}$ & $\begin{array}{l}0.369 \\
(1.12)\end{array}$ & $\begin{array}{l}-0.206 \\
(-0.71)\end{array}$ \\
\hline Strong clawback $\times$ After & $\begin{array}{l}-1.131^{* * *} \\
(-4.40)\end{array}$ & $\begin{array}{l}-1.152^{* * *} \\
(-3.47)\end{array}$ & $\begin{array}{l}-0.474^{*} \\
(-1.93)\end{array}$ \\
\hline Controls, year and industry fixed effects & yes & yes & yes \\
\hline Observations & 2,944 & 2,944 & 2,462 \\
\hline Pseudo $R^{2}$ & $9.89 \%$ & $9.35 \%$ & $17.80 \%$ \\
\hline & CEO total pay & CEO non-incentive pay & CEO incentive pay \\
\hline Strong clawback & $\begin{array}{l}0.053 \\
(0.86)\end{array}$ & $\begin{array}{l}-0.030 \\
(-0.73)\end{array}$ & $\begin{array}{l}0.148^{*} \\
(1.71)\end{array}$ \\
\hline After & $\begin{array}{l}0.102 \\
(1.45)\end{array}$ & $\begin{array}{l}0.052 \\
(0.89)\end{array}$ & $\begin{array}{l}0.102 \\
(1.40)\end{array}$ \\
\hline Strong clawback $\times$ After & $\begin{array}{l}-0.096^{*} \\
(-1.69)\end{array}$ & $\begin{array}{l}-0.027 \\
(-0.57)\end{array}$ & $\begin{array}{l}-0.146^{* *} \\
(-2.52)\end{array}$ \\
\hline Controls, year and industry fixed effects & Yes & yes & yes \\
\hline
\end{tabular}


Table A4 (continued)

\begin{tabular}{|c|c|c|c|}
\hline \multicolumn{4}{|l|}{ Panel C: No non-financial triggers } \\
\hline Observations & 2,462 & 2,462 & 2,462 \\
\hline Adjusted $R^{2}$ & $45.51 \%$ & $32.49 \%$ & $33.99 \%$ \\
\hline \multicolumn{4}{|c|}{ Panel D: Employee coverage sub-index removed from clawback strength index } \\
\hline & Misstatement & Restatement & Turnover \\
\hline \multirow[t]{2}{*}{ Strong clawback } & 0.209 & 0.022 & 0.334 \\
\hline & $(0.66)$ & $(0.07)$ & $(1.15)$ \\
\hline \multirow[t]{2}{*}{ After } & 0.329 & $0.491 * *$ & -0.260 \\
\hline & $(1.54)$ & $(2.36)$ & $(-1.39)$ \\
\hline \multirow{2}{*}{ Strong clawback $\times$ After } & $-0.698 * * *$ & $-1.008 * * *$ & $-0.422^{* * *}$ \\
\hline & $(-3.01)$ & $(-5.26)$ & $(-3.77)$ \\
\hline Controls, year and industry fixed effects & Yes & Yes & yes \\
\hline Observations & 2,935 & 2,935 & 2,441 \\
\hline \multirow[t]{2}{*}{ Pseudo $R^{2}$} & $9.17 \%$ & $9.91 \%$ & $15.60 \%$ \\
\hline & CEO total pay & CEO non-incentive pay & CEO incentive pay \\
\hline \multirow[t]{2}{*}{ Strong clawback } & 0.106 & -0.027 & $0.282^{*}$ \\
\hline & $(1.20)$ & $(-0.46)$ & $(1.83)$ \\
\hline \multirow[t]{2}{*}{ After } & 0.111 & 0.015 & 0.156 \\
\hline & (1.57) & $(0.28)$ & $(1.14)$ \\
\hline \multirow[t]{2}{*}{ Strong clawback $\times$ After } & $-0.152^{* * *}$ & -0.056 & $-0.281 *$ \\
\hline & $(-2.67)$ & $(-0.53)$ & $(-1.86)$ \\
\hline Controls, year and industry fixed effects & yes & yes & yes \\
\hline Observations & 2,441 & 2,441 & 2,441 \\
\hline Adjusted $R^{2}$ & $39.20 \%$ & $31.60 \%$ & $29.90 \%$ \\
\hline
\end{tabular}

Panel E: Higher cut-off point to classify adopters as having strong (weak) clawbacks

\begin{tabular}{|c|c|c|c|}
\hline & Misstatement & Restatement & Turnover \\
\hline Strong clawback & $\begin{array}{l}-0.219 \\
(-0.87)\end{array}$ & $\begin{array}{l}0.043 \\
(0.17)\end{array}$ & $\begin{array}{l}0.313 \\
(1.48)\end{array}$ \\
\hline After & -0.162 & 0.153 & -0.374 \\
\hline Strong clawback $\times$ After & $\begin{array}{l}(-0.61) \\
-0.794 * * \\
(-2.58)\end{array}$ & $\begin{array}{l}(0.45) \\
-1.044 * * \\
(-2.44)\end{array}$ & $\begin{array}{l}(-1.20) \\
-0.475^{* * *} \\
(-3.24)\end{array}$ \\
\hline Controls, year and industry fixed effects & Yes & yes & yes \\
\hline Observations & 2,074 & 2,074 & 1,572 \\
\hline \multirow[t]{2}{*}{ Pseudo $R^{2}$} & $13.30 \%$ & $9.67 \%$ & $20.90 \%$ \\
\hline & CEO total pay & CEO non-incentive pay & CEO incentive pay \\
\hline Strong clawback & $\begin{array}{l}0.184 * \\
(1.69)\end{array}$ & $\begin{array}{l}0.128^{*} \\
(1.78)\end{array}$ & $\begin{array}{l}0.375^{* *} \\
(2.47)\end{array}$ \\
\hline After & $\begin{array}{l}0.229 \\
(1.52)\end{array}$ & $\begin{array}{l}0.116 \\
(1.13)\end{array}$ & $\begin{array}{l}0.370^{* *} \\
(1.98)\end{array}$ \\
\hline Strong clawback $\times$ After & $\begin{array}{l}-0.229 \\
(-1.76)\end{array}$ & $\begin{array}{c}-0.090 \\
(-0.96)\end{array}$ & $\begin{array}{l}-0.357^{* *} \\
(-2.00)\end{array}$ \\
\hline Controls, year and industry fixed effects & Yes & yes & yes \\
\hline Observations & 1,572 & 1,572 & 1,572 \\
\hline Adjusted $R^{2}$ & $35.31 \%$ & $26.61 \%$ & $30.06 \%$ \\
\hline
\end{tabular}

This table presents robustness tests on the Clawback Strength Index construction. In Panel A we set the Trigger sub-index equal to zero if the provision explicitly mentions that a potential clawback requires personal misconduct on part of the executive. In Panel B we multiply, rather than sum up, the Trigger sub-index with the sum of all remaining four sub-indices. In Panel C we remove non-financial triggers and related index components that have no direct relation to reporting integrity from the Clawback Strength Index. In Panel D we exclude the Employee Coverage sub-index from the Clawback Strength Index. In Panel E we set the cut-off point to classify adopters as having strong (weak) clawbacks at the 75th- (25th-) percentile of the yearly Clawback Strength Index distribution. We propensity-match strong adopters to weak adopters based on the alternative classifications of strong and weak adopters. Continuous variables are winsorized at $1 \%$ and $99 \%$, and all variables are described in Appendix A. Standard errors are robust to clustering at the year and firm levels. Z/T-values are in parentheses. ***, **, and * denote significance at the $1 \%$, 5\%, and 10\% level, respectively. 


\begin{tabular}{|c|c|c|}
\hline Variable & Description & Data Source \\
\hline \multicolumn{3}{|c|}{ Firm-specific Variables } \\
\hline After & 1 for periods following clawback adoption, and 0 otherwise & Own computation \\
\hline Altman Z-score & Calculation based on Altman (1968) & Compustat \\
\hline Big 4 & 1 if the firm is audited by a BIG 4 audit company, and 0 otherwise & Compustat \\
\hline Book-to-market & Book value of equity divided by market value of equity & Compustat; CRSP \\
\hline Capital intensity & Gross PPE divided by total net sales & Compustat \\
\hline Cash return & $\begin{array}{l}\text { Earnings before interest, taxes, depreciation, and amortization divided by lagged } \\
\text { total assets }\end{array}$ & Compustat \\
\hline $\begin{array}{l}\text { Chg. in accounts } \\
\text { receivables }\end{array}$ & Change in accounts receivables divided by trailing two years average total assets & Compustat \\
\hline Clawback Strength & Sum of five standardized and $[0 ; 1]$-transformed sub-indices: Compensation & Corporate Library; \\
\hline Index & $\begin{array}{l}\text { Coverage }+ \text { Employee Coverage }+ \text { Enforcement }+ \text { Time Period }+ \text { Trigger. Each } \\
\text { sub-index is based on a linguistic analysis of a firm's clawback provision obtained } \\
\text { from the Corporate Library. The higher the index value, the stronger a clawback } \\
\text { provision. }\end{array}$ & own computation \\
\hline Current ratio & Current assets divided by current liabilities & Compustat \\
\hline Debt issuance & 1 if the firm issues public debt and 0 otherwise & Compustat \\
\hline $\begin{array}{l}\text { Discretionary } \\
\text { accruals }\end{array}$ & $\begin{array}{l}\text { Absolute value of performance-adjusted discretionary accruals according to the } \\
\text { modified Jones model }\end{array}$ & Compustat \\
\hline Downward revision & $\begin{array}{l}1 \text { if the last available forecast of current-year EPS is less than the first forecast of } \\
\text { current-year EPS, and } 0 \text { otherwise }\end{array}$ & $\mathrm{I} / \mathrm{B} / \mathrm{E} / \mathrm{S}$ \\
\hline Earnings growth & 1 if change in net income is positive, and 0 otherwise & Compustat \\
\hline Earnings surprise & $\begin{array}{l}\text { Difference between reported EPS and analysts' consensus EPS estimate scaled by } \\
\text { closing price of the period }\end{array}$ & I/B/E/S; CRSP \\
\hline $\begin{array}{l}\text { Extraordinary } \\
\quad \text { items }\end{array}$ & 1 if the firm reports extraordinary items, and 0 otherwise & Compustat \\
\hline Foreign sales & Ratio of foreign sales to total sales & Compustat \\
\hline $\begin{array}{l}\text { Fourth fiscal } \\
\text { quarter }\end{array}$ & 1 if the quarter is the fourth fiscal quarter, and 0 otherwise & Compustat \\
\hline Industry & Indicator variables for Fama-French industries & Compustat \\
\hline Internationalization & Foreign sales/Total sales & Compustat \\
\hline Inventory & Natural logarithm of inventory & Compustat \\
\hline Leverage & Long-term debt plus debt in current liabilities divided by total book assets & Compustat \\
\hline Loss & 1 if the firm reports a net loss in the period, and 0 otherwise & Compustat \\
\hline Misstatement & 1 for firm-years that belong to a restatement period, and 0 otherwise & Audit Analytics \\
\hline $\begin{array}{l}\text { Number of } \\
\text { estimates }\end{array}$ & Number of EPS estimates included in calculation of consensus estimate & $\mathrm{I} / \mathrm{B} / \mathrm{E} / \mathrm{S}$ \\
\hline Past meet-beat & $\begin{array}{l}1 \text { if the firm reported a positive earnings surprise in the previous quarter, and } 0 \\
\text { otherwise }\end{array}$ & $\mathrm{I} / \mathrm{B} / \mathrm{E} / \mathrm{S}$ \\
\hline Past restatement & 1 if a firm had an earnings restatement in the trailing two years, and 0 otherwise & Audit Analytics \\
\hline$R \& D$ & Research and development expenditures divided by total sales & Compustat \\
\hline Restatement & $\begin{array}{l}1 \text { for the first fiscal year that is affected by improper accounting that later } \\
\text { necessitated a restatement, and zero otherwise }\end{array}$ & Audit Analytics \\
\hline Return on assets & Income before extraordinary items divided by lagged total assets & Compustat \\
\hline Return volatility & Yearly standard deviation of a firm's daily return & CRSP \\
\hline Sales growth & One-year growth in total sales & Compustat \\
\hline SEO & 1 if the firm issues common stock, and 0 otherwise & Compustat \\
\hline Size & Natural logarithm of total assets & Compustat \\
\hline Share return & Lagged yearly stock return & CRSP \\
\hline Soft assets & $\begin{array}{l}\text { Soft assets divided by total book assets, with soft assets defined as total assets - total } \\
\text { property, plant, and equipment (net) - cash and short-term investments }\end{array}$ & Compustat \\
\hline Strong clawback & $\begin{array}{l}1 \text { if the Clawback Strength Index of a firm's clawback provision is above the yearly } \\
\text { sample median, and } 0 \text { otherwise }\end{array}$ & Own computation \\
\hline Tobin's $Q$ & $\begin{array}{l}\text { Book value of long-term debt and debt in current liabilities plus the market } \\
\text { capitalization of the firm divided by total book assets }\end{array}$ & Compustat; CRSP \\
\hline Turnover & 1 if there is a CEO turnover, and 0 otherwise & ExecuComp \\
\hline
\end{tabular}


Underperformance 1 if a firm's share return is smaller than the yearly industry share return, and $0 \quad$ CRSP otherwise

Write-off $\quad 1$ is special items is negative, and 0 otherwise

Governance Variables

Audit committee Two-year moving average of the total number of audit committee members

size

Board meetings

CEO age

CEO chair

CEO tenure

Independent directors

Insider ownership

Institutional ownership

CEO Pay Variables

CEO incentive pay

CEO non-incentive

pay

CEO total pay
Number of board meetings held by a firm's board of directors

1 for CEOs aged 64, 65, or 66, and 0 otherwise following Weisbach (1988)

1 if the CEO is also chairman of the board of directors, and 0 otherwise

Natural logarithm of a CEO's tenure (in years)

Fraction of independent directors on a firm's board of directors

Fraction of outstanding shares held by a firm's top management team

Percentage of shares held by institutional investors

Natural logarithm of total minus non-incentive pay

Natural logarithm of the sum of salary and other pay

Natural logarithm of total pay
Compustat

Corporate library

Corporate library

Corporate library

Corporate library

ExecuComp

Corporate library

Corporate library

Thomson reuters

ExecuComp

ExecuComp

ExecuComp

\section{Appendix B. Index construction}

We develop a Clawback Strength Index from a linguistic analysis of 4,464 clawback provisions by 1,534 firms. We identify five dimensions of clawbacks. Each dimension represents a core element of a clawback and is reflected in a sub-index, all of which add up to the Clawback Strength Index. In this appendix, we briefly explain each sub-index. Please see Internet Appendix B for a more detailed description of the index itself.

\section{Compensation coverage sub-index}

The Compensation Coverage sub-index captures which types of compensation are subject to a forfeiture. A clawback provision is stronger if it explicitly lists more compensation types. We add one point for each type of compensation covered, and one point if the provision covers compensation up to the full amount.

\section{Employee coverage sub-index}

The Employee Coverage sub-index focuses on the various groups of employees and/or individuals covered under the clawback. The broader the employee coverage, the higher the score in the sub-index. We add two points to the Employee Coverage sub-index if the policy mentions that it covers "employees" in general. We add only one point if it mentions "NEOs," "executives," or both. We add another point if the provision explicitly mentions that all executives/employees are covered and if the provision covers former executives/employees. If the provision explicitly lists certain executives (e.g., the CEO or CFO), we add 0.20 points for each listed function. We do not count coverage twice (e.g., mentioning the CEO and NEOs will increase the index by one point, not by 1.20 points).

\section{Enforcement sub-index}

Clawbacks contain a considerable amount of discretion over enforcement. This discretion is captured by the Enforcement subindex. Firms receive a higher Enforcement sub-index score for the less discretion they grant in activating a clawback. If the provision explicitly states that the board is obligated to recoup excess pay, we add one point to the Enforcement sub-index. If the firm has only the right or option to enforce a clawback, we add 0.75 points to the sub-index. If the policy explicitly mentions the board's discretion to enforce a recoupment, we subtract 0.25 points from the sub-index. Finally, we add 0.25 points if the policy mentions additional actions, such as the termination of employment.

Time period sub-index

The Time Period sub-index distinguishes clawback provisions in terms of their look-back period, which specifies how far a firm can go back in time to recoup the compensation it had paid to its employees during that period. The score for the Time Period sub-index increases with the length of the look-back period. As we have identified five look-back periods, we add one point if the look-back is shorter than or equal to six months, two points if the period is between six and 12 months, three points if the period is between 12 and 24 months, four points if the period is between 24 months and 36 months, and five points if the period is longer than 36 months. 
Trigger sub-index

The Trigger sub-index captures the events that trigger a clawback. We group triggering events into financial and non-financial triggers. We add one point if a provision contains at least one financial trigger, and one point if it contains at least one non-financial trigger.

We also check whether the triggering events are linked to hurdles to recovery and identify three hurdles: materiality, misbehavior, and deliberateness. These hurdles reduce the likelihood of a potential recoupment. For example, a firm will find it easier to activate a clawback if it does not need to prove executive misconduct (misbehavior hurdle involved). We consider only whether a hurdle is mentioned or not. For each hurdle, we subtract 0.25 points from the Trigger sub-index, resulting in a maximum discount of 0.75 points. Firms that introduce objectively identifiable triggering events and no hurdles to recovery receive a higher sub-index score.

Summary

The following table shows how we assign the points to each sub-index. The column "Number of observations" details how many provisions contain the respective component; the column "\% of total" indicates the number of observations for each component by the total number of clawback provisions $(4,464)$.

\begin{tabular}{llll}
\hline Sub-index & Points & $\begin{array}{l}\text { Number of } \\
\text { obs. }\end{array}$ & $\begin{array}{l}\% \text { of } \\
\text { total }\end{array}$
\end{tabular}

(1) Compensation coverage

Incentive compensation

Indirect profits (e.g., stock sale gains)

Deferred compensation

Other compensation

Stock (option) compensation

Cash compensation

Up to the full amount

(2) Employee coverage

Explicitly: Executives

Explicitly: Employees

Explicitly: NEO

Explicitly: all employees or executives

Explicitly: former employees or executives

Explicitly: CEO

Explicitly: CFO

Explicitly: other functions (CAO, $\mathrm{COO}$ etc.)

(3) Enforcement

Words indicating that the board is obligated to claw 1 back

Words indicating that the board has discretion to $\quad-0.25$ claw back

Words indicating that the board has the right to claw 0.75 back

Words indicating additional actions $\quad 0.2$

(4) Time period

Shorter/equal 6 months

1

Shorter/equal 12 months and larger than 6 months 2

Shorter/equal 24 months and larger than 12 months 3

Shorter/equal 36 months and larger than 24 months 4

Longer than 36 months

(5) Trigger

Financial triggers

Non-financial triggers

\begin{tabular}{|c|c|c|c|c|}
\hline 1 & 2,982 & 66.8 & 0 & 1 \\
\hline 1 & 826 & 18.5 & 0 & 1 \\
\hline 1 & 409 & 9.2 & 0 & 1 \\
\hline 1 & 275 & 6.2 & 0 & 1 \\
\hline 1 & 181 & 4.1 & 0 & 1 \\
\hline 1 & 166 & 3.7 & 0 & 1 \\
\hline 1 & 1,213 & 27.2 & 0 & 1 \\
\hline 1 & 2,618 & 58.6 & 0 & 1 \\
\hline 2 & 1,439 & 32.2 & 0 & 2 \\
\hline 1 & 1,034 & 23.2 & 0 & 1 \\
\hline 1 & 920 & 20.6 & 0 & 1 \\
\hline 1 & 362 & 8.1 & 0 & 1 \\
\hline 0.2 & 108 & 2.4 & 0 & 0.2 \\
\hline 0.2 & 78 & 1.8 & 0 & 0.2 \\
\hline 0.2 & 35 & 0.8 & 0 & 0.2 \\
\hline 1 & 2,240 & 50.2 & 0 & 1 \\
\hline-0.25 & 2,162 & 48.4 & -0.25 & 0 \\
\hline 0.75 & 782 & 17.5 & 0 & 0.75 \\
\hline 0.25 & 624 & 14.0 & 0 & 0.25 \\
\hline 1 & 46 & 1.0 & 0 & 1 \\
\hline 2 & 352 & 7.9 & 0 & 2 \\
\hline 3 & 170 & 3.8 & 0 & 3 \\
\hline 4 & 538 & 12.1 & 0 & 4 \\
\hline 5 & 134 & 3.0 & 0 & 5 \\
\hline Financial restatement & 1 & 3,606 & 80.8 & 0 \\
\hline Financial misstatement & & 239 & 5.4 & \\
\hline Poor performance & & 8 & 0.2 & \\
\hline Write-off & & 7 & 0.2 & \\
\hline $\begin{array}{l}\text { Breach of post-empl. } \\
\text { agreements }\end{array}$ & 1 & 655 & 14.7 & 0 \\
\hline Negligence of duty & & 344 & 7.7 & \\
\hline Criminal behavior & & 314 & 7.0 & \\
\hline Termination for cause & & 280 & 6.3 & \\
\hline Early departure & & 17 & 0.4 & \\
\hline
\end{tabular}


Hurdles to recovery

\author{
Materiality \\ Misbehavior \\ Deliberateness
}

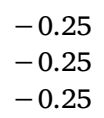

2,732

2,478

1,488
$61.2-0.25 \quad 0$

$55.5-0.25 \quad 0$

\section{References}

Armstrong, C.S., Jagolinzer, A.D., Larcker, D.F., 2010. Chief executive officer equity incentives and accounting irregularities. J. Account. Res. 48, 225-271. Ashbaugh-Skaife, H., Collins, D.W., Kinney Jr, W.R., 2007. The discovery and reporting of internal control deficiencies prior to SOX-mandated audits. J. Account. Econ. 44, 166-192.

Bennett, B., Bettis, J.C., Gopalan, R., Milbourn, T., 2017. Compensation goals and firm performance. J. Financ. Econ. 124, 307-330.

Bliss, R.R., Panigirtzoglou, N., 2004. Option-implied risk aversion estimates. J. Finance LIX, 407-446.

Burgstahler, D., Chuk, E., 2015. Do scaling and selection explain earnings discontinuities. J. Account. Econ. 60, 168-186.

Chan, L.H., Chen, K.C.W., Chen, T.-Y., 2013. The effects of firm-initiated clawback provisions on bank loan contracting. J. Financ. Econ. 110 , 659-679.

Chan, L.H., Chen, K.C.W., Chen, T.-Y., Yu, Y., 2012. The effects of firm-initiated clawback provisions on earnings quality and auditor behavior. J. Account. Econ. 54, $180-196$.

Chan, L.H., Chen, K.C.W., Chen, T.Y., Yu, Y., 2015. Substitution between real and accruals-based earnings management after voluntary adoption of compensation clawback provisions. Account. Rev. 90 (1), 147-174.

Chhaochharia, V., Grinstein, Y., 2009. Corporate governance and firm value: The impact of the 2002 governance rules. J. Finance 62 , $1789-1825$.

Core, J., Guay, W., Verrecchia, R., 2003. Price versus non-price performance measures in optimal CEO compensation contracts. Account. Rev. 78, 957-981.

deHaan, E., Hodge, F., Shevlin, T., 2013. Does voluntary adoption of a clawback provision improve financial reporting quality? Contemp. Account. Res. 30, $1027-1062$.

Denis, D.K., 2001. Twenty-five years of corporate governance research . . . and counting. Rev. Financ. Econ. 10, $191-212$.

Denis, D.K., 2012. Mandatory clawback provisions, information disclosure, and the regulation of securities markets. J. Account. Econ. 54, $197-200$.

Desai, H., Hogan, C.E., Wilkins, M.S., 2006. The reputational penalty for aggressive accounting: earnings restatements and management turnover. Account. Rev. 81, 83-112.

Dicks, D.L., 2012. Executive compensation and the role for corporate governance regulation. Rev. Financ. Stud. 25, $1971-2004$.

Doyle, J., Ge, W., McVay, S., 2007. Determinants of weaknesses in internal control over financial reporting. J. Account. Econ. 44, $193-223$.

Engel, E., Hayes, R.M., Wang, X., 2010. Audit committee compensation and the demand for monitoring of the financial reporting process. J. Account. Econ. 49, $136-154$.

Francis, J., LaFond, R., Olsson, P., Schipper, K., 2005. The market pricing of accruals quality. J. Account. Econ. 39, $295-327$.

Fried, J., Shilon, N., 2011. Excess-pay clawbacks. J. Corp. Law 36, 721-751.

Gow, I.D., Ormazabal, G., Taylor, D.J., 2010. Correcting for cross-sectional and time-series dependence in accounting research. Account. Rev. 85, 483-512.

Graham, J.R., Harvey, C.R., Rajgopal, S., 2005. The economic implications of corporate financial reporting. J. Account. Econ. 40 , 3-73.

Hall, B.J., Liebman, J.B., 1998. Are CEOs really paid like bureaucrats? Q. J. Econ. 113, 653-691.

Haubrich, J.G., 1994. Risk aversion, performance pay, and the principal-agent problem. J. Polit. Econ. 102, 258-276.

Hennes, K.M., Leone, A.J., Miller, B.P., 2008. The importance of distinguishing errors from irregularities in restatement research: the case of restatements and CEO/ CFO turnover. Account. Rev. 83, 1487-1519.

Hermanson, D.R., Smith, J.L., Stephens, N.M., 2012. How effective are organizations' internal controls? Insights into specific internal control elements. Curr. Issues Audit. 6, 31-50.

Hoitash, R., Hoitash, U., Kurt, A.C., 2016. Do accountants make better chief financial officers? J. Account. Econ. 61, 414-432.

Hölmstrom, B., 1979. Moral hazard and observability. Bell J. Econ. 10, 74-91.

Hosman, C.A., Hansen, B.B., Holland, P.W., 2010. The sensitivity of linear regression coefficients' confidence limits to the omission of a confounder. Ann. Appl. Stat. 4, 849-870.

Hribar, P., Kravet, T.D., Wilson, R., 2014. A new measure of accounting quality. Rev. Account. Stud. 19, 509-538.

Imbens, G.W., Wooldridge, J.M., 2009. Recent developments in the econometrics of program evaluation. J. Econ. Lit. 47, 5-86.

Iskandar-Datta, M., Jia, Y., 2013. Valuation consequences of clawback provisions. Account. Rev. 88, 171-198.

Jayaraman, S., Milbourn, T., 2015. CEO equity incentives and financial misreporting: the role of auditor expertise. Account. Rev. 90, 321-350.

Laux, C., Laux, V., 2009. Board committees, CEO compensation, and earnings management. Account. Rev. 84, 869-891.

Li, Z., Wang, L., 2016. Executive compensation incentives contingent on long-term accounting performance. Rev. Financ. Stud. 29, 1586-1633.

Lien, G., 2002. Non-parametric estimation of decision makers' risk aversion. Agric. Econ. 27, 75-83.

Liu, J., Thomas, J., 2000. Stock returns and accounting earnings. J. Account. Res. 38, 71-101.

Murphy, K.J., 1999. Executive compensation. Handbook of Labor Economics 3. pp. 2485-2563.

Roberts, M., Whited, T.M., 2013. Endogeneity in empirical corporate finance. In: Constantinides, G.M., Harris, M., Stulz, R.M. (Eds.), Handbook of the Economics of Finance, pp. 493-572.

Rosenbaum, P.R., 2002. Observational Studies, second ed. Springer, New York.

Shipman, J.E., Swanquist, Q.T., Whited, R.L., 2017. Propensity score matching in accounting research. Account. Rev. 92 (1), $213-244$.

Wagner, S., Dittmar, L., 2006. The Unexpected Benefits of Sarbanes-Oxley. Harvard Business Review April 2006.

Weisbach, M.S., 1988. Outside directors and CEO turnover. J. Financ. Econ. 20, 431-460.

Westphal, J.D., Graebner, M.E., 2010. A matter of appearances: how corporate leaders manage the impressions of financial analysts about the conduct of their boards. Acad. Manage. J. 53, 15-44. 